\title{
Sources of high-chloride water and managed aquifer recharge in an alluvial aquifer in California, USA
}

\author{
David R. O'Leary • John A. Izbicki • Loren F. Metzger
}

\begin{abstract}
As a result of pumping in excess of recharge, water levels in alluvial aquifers within the Eastern San Joaquin Groundwater Subbasin, $130 \mathrm{~km}$ east of San Francisco (California, USA), declined below sea level in the early 1950s and have remained so to the present. Chloride concentrations in some wells increased during that time and exceeded the US Environmental Protection Agency's secondary maximum contaminant level of $250 \mathrm{mg} / \mathrm{L}$, resulting in removal of some wells from service. Sources of high-chloride water include irrigation return in $16 \%$ of sampled wells and water from delta sediments and deeper groundwater in $50 \%$ of sampled wells. Chloride concentrations resulting from irrigation return commonly did not exceed $100 \mathrm{mg} / \mathrm{L}$, although nitrate concentrations were as high as $25 \mathrm{mg} / \mathrm{L}$ as nitrogen. Chloride concentrations ranged from less than $100-2,050 \mathrm{mg} / \mathrm{L}$ in wells affected by water from delta sediments and deeper groundwater. Sequential electromagnetic logs show movement of highchloride water from delta sediments to pumping wells through permeable interconnected aquifer layers. $\delta \mathrm{D}$ and $\delta^{18} \mathrm{O}$ data show most groundwater originated as recharge along the front of the Sierra Nevada, but tritium and carbon14 data suggest recharge rates in this area are low and have decreased over recent geologic time. Managed aquifer recharge at two sites show differences in water-level responses to recharge and in the physical movement of recharged water with depth related to subsurface geology. Well-bore flow logs also show rapid movement of water from recharge sites through permeable interconnected aquifer layers to pumping wells.
\end{abstract}

Received: 30 January 2015 / Accepted: 1 June 2015

Published online: 3 July 2015

(C) The Author(s) 2015. This article is published with open access at Springerlink.com

Electronic supplementary material The online version of this article (doi:10.1007/s10040-015-1277-7) contains supplementary material, which is available to authorized users.

D. R. O'Leary ( $) \cdot$ J. A. Izbicki

US Geological Survey, 4165 Spruance Road, San Diego, CA

92109, USA

e-mail: doleary@usgs.gov

L. F. Metzger

US Geological Survey, 6000 J Street, Sacramento, CA 95819, USA
Keywords Water supply - Groundwater recharge/water budget - Groundwater management · Heterogeneity · USA

\section{Introduction}

Chloride concentrations are increasing in coastal aquifers as a result of groundwater pumping in many areas of California (Edwards et al. 2009; Hanson 2003; Reichard et al. 2003; Izbicki 1996) and elsewhere (Tularam and Krishna 2009; Barlow and Reichard 2010). As early as 1905 Mendenhall (1905) recognized that increasing water levels would slow or stop seawater intrusion. Since that time numerous studies have shown that seawater intrusion and intrusion of high-chloride water from other sources can be mitigated by increasing water levels through reduced pumping coupled with increased recharge (Hammer and Elser 1980; Reichard 1995; Shammas 2008; Metropolitan Water District of Southern California 2007).

In addition to seawater intrusion, other possible sources of high-chloride water in near-coastal aquifers include: (1) water from deposits or rocks that are adjacent to or underlie freshwater aquifers, (2) soluble salts emplaced in sediments by the evaporation of groundwater in discharge areas, and (3) irrigation return water (Piper and Garrett 1953; Izbicki et al. 2006). Numerous techniques are available and have been used to identify sources of chloride; for example, Anders et al. (2013) used geochemical data in a deep coastal aquifer system in the San Diego area to discern sources of salinity that included paleo-seawater intrusion and mobilization of salts from saline sediments by fresh regional groundwater flow; Izbicki et al. (2005) used flowmeter and depth-dependent water-quality data to determine that high-chloride water was entering long-screened production wells from both shallow and deep depths in a coastal California aquifer; Metzger and Izbicki (2012) and O'Leary et al. (2012) showed that this water could move rapidly through aquifers in thin permeable layers within alluvial deposits.

In the Eastern San Joaquin Groundwater Subbasin, near Stockton, California, $130 \mathrm{~km}$ east of San Francisco (Fig. 1), pumping in excess of recharge and resulting declines in water levels within aquifers to below sea level (Fig. 2) has led to an increase in chloride concentrations in 

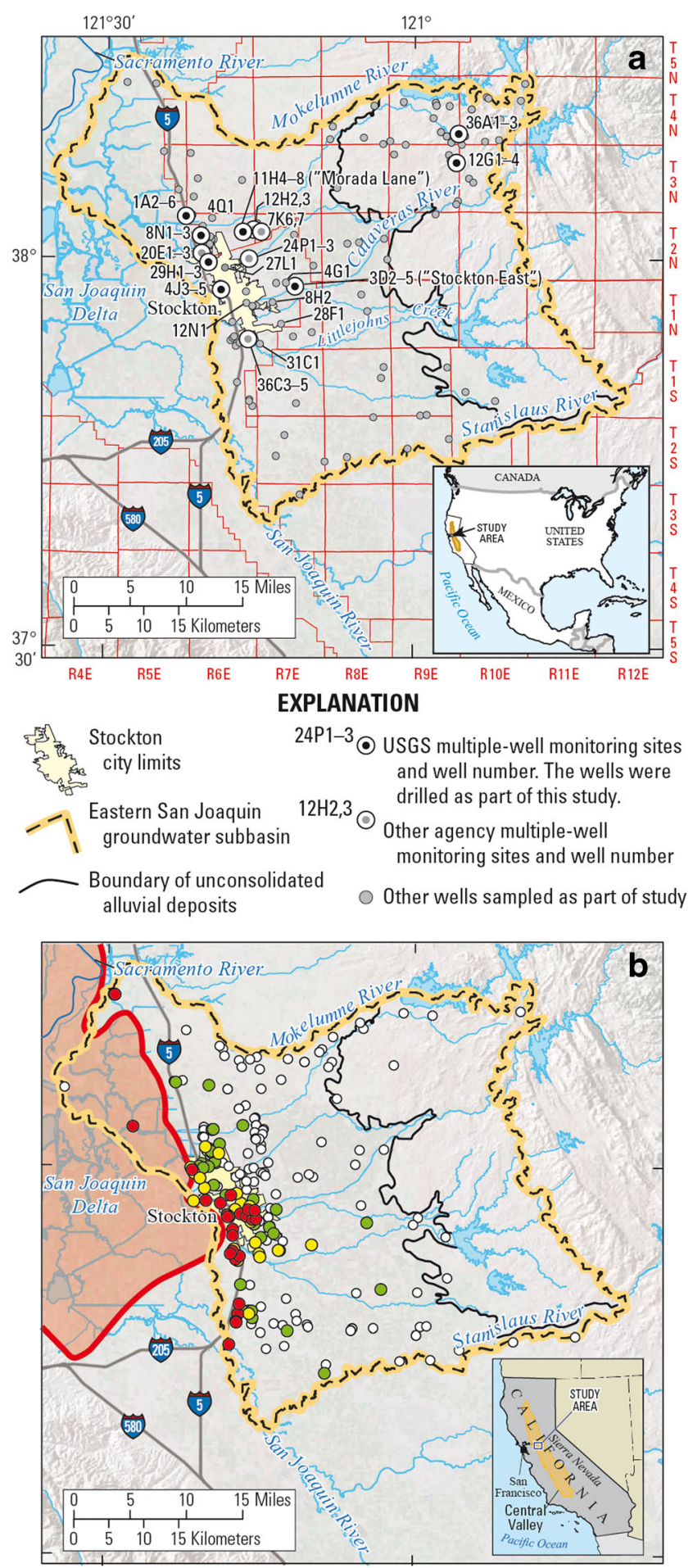

EXPLANATION

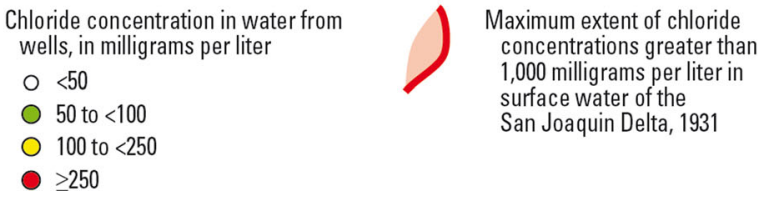

Fig. 1 Map of Eastern San Joaquin Groundwater Subbasin, California, showing: a location of study area; and $\mathbf{b}$ chloride concentrations in water from wells (modified from Piper et al. 1939)

Hydrogeology Journal (2015) 23: 1515-1533 water from wells (Izbicki et al. 2006). This trend began in the 1950s and has led to exceedances of the US Environmental Protection Agency (USEPA) secondary maximum contaminant level (SMCL) of $250 \mathrm{mg} / \mathrm{L}$ for chloride in several wells (California Department of Water Resources 1967). In an effort to mitigate the impact of high-chloride water on groundwater supplies, local agencies, led by the Eastern San Joaquin County Groundwater Basin Authority in cooperation with the California Department of Water Resources (DWR), Stockton East Water District, and the City of Stockton, implemented strategies involving the conjunctive use of surface water and groundwater to meet demand. Supplementing natural recharge with managed aquifer recharge can increase water levels and improve water quality by limiting movement of high-chloride water into freshwater aquifers. Artificial recharge programs have also been implemented that promote infiltration of captured local runoff to manage declining water levels and chloride concentrations. Programs include Stockton East Water District's Farmington Groundwater Recharge Program, with a goal of recharging about $43 \times 10^{6} \mathrm{~m}^{3}$ year annually through field-flooding (Stockton East Water District 2014) and the City of Stockton's Morada Recharge Facility, which utilizes an existing stormflow basin to infiltrate local surface water and stormflow runoff (O'Leary et al. 2012). The Stockton East and Morada recharge facilities have been in operation since 2003 and occupy about 5 and 25 ha, respectively.

A groundwater flow model of the Central Valley that included the subbasin was developed by Faunt (2009). The subbasin was investigated as part of the Groundwater Ambient Monitoring and Assessment (GAMA) study of the larger Northern San Joaquin Basin in 2004 and 2005 (Bennett et al. 2010), which found concentrations of chloride above the SMCL in $3.4 \%$ of the aquifer pumped for water supply.

The purpose of this study is to evaluate sources of high-chloride water and the effect of managed aquifer recharge on water levels and movement of water to wells at two sites in the Northeastern San Joaquin Groundwater Subbasin. The scope of the work included: (1) test-drilling and installation of monitoring wells, (2) collection of chemical and isotopic data from existing domestic and production wells and from monitoring wells installed as part of this study, (3) collection of flow logs from pumped and unpumped wells, and (4) collection of sequential electromagnetic (EM) logs from monitoring wells.

\section{Hydrogeologic setting}

The study area is the Eastern San Joaquin Groundwater Subbasin near Stockton, California. The subbasin is about $2,900 \mathrm{~km}^{2}$ (California Department of Water Resources 2006) and is within the San Joaquin Valley of California (Fig. 1). The climate is characterized by hot, dry summers, and cool, moist winters. Average annual precipitation in Stockton averages about $360 \mathrm{~mm}$ (Western Regional 

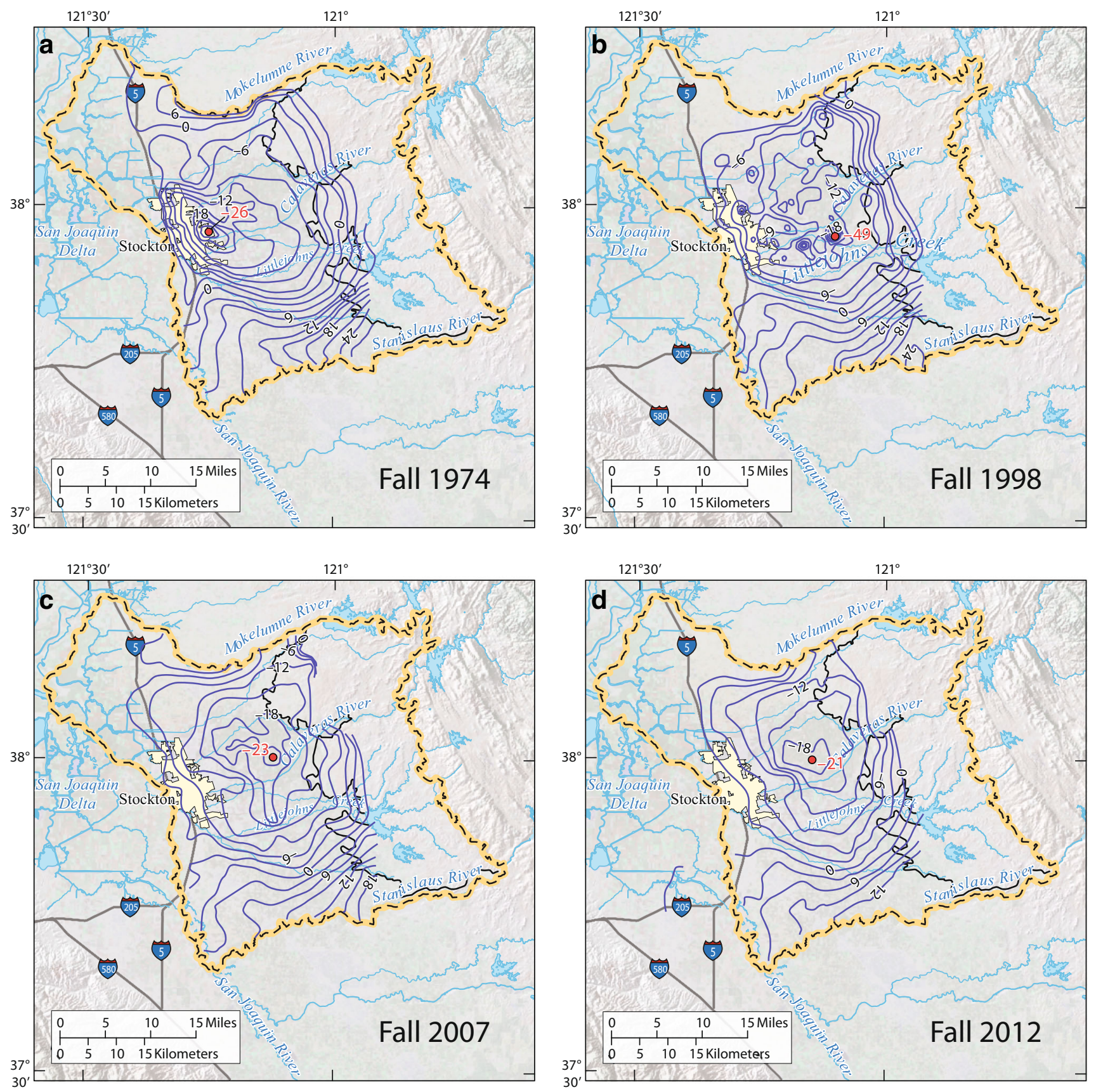

\section{EXPLANATION}
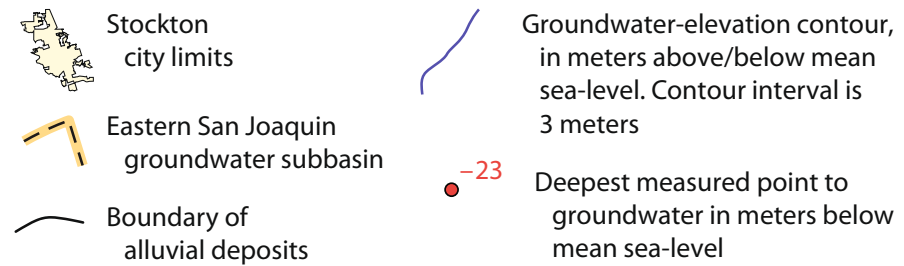

Fig. 2 Maps showing historic water levels, Eastern San Joaquin Groundwater Subbasin: a 1974, b 1998, c 2007, and d 2012. Water levels reported by San Joaquin County Public Works Department, Water Resources Division (2014)

Climate Center 2012), falling primarily in November through December. Precipitation increases with elevation to the east in the foothills of the Sierra Nevada Mountains. The Mokelumne and Stanislaus rivers, which bound the Hydrogeology Journal (2015) 23: 1515-1533 study area to the north and south, respectively, have their headwaters in the Sierra Nevada (Fig. 1). The Sierra Nevada form the eastern boundary of the study area and the San Joaquin River and its delta bounds the study area 
to the west. Before the construction of reservoirs on the San Joaquin and Sacramento rivers and their tributaries, seawater intruded the delta during periods of low flow (Piper et al. 1939). Current management practices maintain freshwater surface flows in the delta, preventing the inland movement of seawater through the delta.

The subbasin is underlain by several hundred meters of consolidated, partly consolidated, and unconsolidated sedimentary deposits (California Dept. of Water Resources 1967). The oldest deposits are marine and generally contain saline water, except where they outcrop near the foothills of the Sierra Nevada. The marine deposits are overlain by alluvial-fan deposits and delta deposits of the San Joaquin River. Groundwater in these overlying deposits is generally unconfined, although some confinement may be present at depth as a result of discontinuous fine-textured sediment lenses present throughout the alluvial fan sediments of the eastern San Joaquin Valley (Burow et al. 2004).

The Corcoran Clay Member of the Tulare Formation, a confining layer that separates upper and lower aquifer systems throughout much of the San Joaquin Valley is not present in the Stockton area (Faunt 2009). In the Stockton area, volcanic deposits, known as the Mehrten Formation, separate overlying alluvial-fan and delta deposits from underlying marine deposits and form the effective base of freshwater. Volcanic debris flows (lahars) within the Mehrten have low permeability and act as confining layers where they are aerially extensive (Curtis 1954). These low-permeability deposits are blanketed by a layer of alluvium eroded from these same deposits. The volcanic deposits are at about $300 \mathrm{~m}$ below land surface (bls) in the Stockton area and exist at shallower depths to the east toward the foothills of the Sierra Nevada. Natural gas wells drilled in the Stockton area in the 1880s penetrated to depths below the volcanic deposits and experienced artesian conditions with saline water discharging at the surface (Mendenhall 1908). Some of this saline water was used for recreational swimming pools, the most famous of which, the Jackson Baths, was in south Stockton at McKinley Park (Downtown Stockton Alliance 2008).

Under predevelopment conditions (prior to the onset of extensive groundwater pumping) groundwater flow in alluvial-fan deposits within the subbasin was generally from the Sierra Nevada in the east toward the San Joaquin River and delta in the west. Surface water infiltrated from the upstream reaches of rivers and streams into the underlying alluvial deposits, while groundwater discharged along the downstream reaches (Piper et al. 1939). Historically, groundwater discharge to springs and seeps was fresh and low in dissolved solids (Mendenhall 1908)

Groundwater recharge within the Eastern San Joaquin Groundwater Subbasin is about $1.11 \times 10^{9} \mathrm{~m}^{3} /$ year. Groundwater pumping increased through the twentieth century; and pumpage exceeds recharge by $1.85 \times 10^{8} \mathrm{~m}^{3} /$ year (Northeastern San Joaquin County Groundwater Banking Authority 2004). As a result of pumping in excess of recharge, water levels in parts of the subbasin declined to below sea level in the early 1950s (California Dept. of Water Resources 1967). The pumping depression has expanded and shifted eastward in recent years, with water levels remaining as much as $21 \mathrm{~m}$ below sea level in 2012 in the deepest part of the pumping depression (Fig. 2).

\section{Methods}

\section{Test drilling, well installation, and water-level monitoring}

Eight multiple-well monitoring sites were installed by the US Geological Survey (USGS) in the study area between 2003 and 2012. Lithologic logs and selected geophysical logs-including caliper, fluid temperature, spontaneous potential, natural gamma, long and short normal electrical resistivity logs, and lateral logs-were collected during drilling to guide well installation. Three to five, $5-\mathrm{cm}-$ diameter PVC wells were installed in each mud-rotary drilled borehole. The annulus surrounding the wells screens was backfilled with sand and the remainder of the annulus was backfilled with low-permeability bentonite grout. Drilling, geophysical log, and construction data typically collected during installation of a multiple-well site are shown for multiple well sites 2 N/6E-11H4-8 (11H4-8; STK-2) and 1 N/7E-3D2-5 (3D2-5; STK-7) at the Morada Lane and Stockton East recharge facilities (respectively) in Figs. S1 and S2 of the electronic supplementary material (ESM). Drilling, construction, and sampling information for USGS wells drilled as part of this study are provided by Clark et al. (2012). Summary data regarding multiple-well monitoring sites are presented in Table S1 of the ESM. Five additional multiple-well sites, installed by other organizations, were monitored and sampled as part of this study (Table S1 of the ESM).

Water levels were periodically measured at all of the multiple-well sites. Continuous water-level data were collected from 23 monitoring wells at selected multiplewell sites installed as part of this study and from 10 monitoring wells at 3 existing multiple-well sites in the study area (Clark et al. 2012; Metzger et al. 2012).

\section{Sample collection and laboratory methods}

About 200 water samples were collected from 90 wells in the study area during 2003-2012 (Clark et al. 2012; Metzger et al. 2012). Samples were collected from domestic, production (including agricultural, public-supply, and industrial wells), and monitoring wells after three casing volumes were removed from the well and field parameters (temperature, specific conductance, and $\mathrm{pH}$ ) stabilized using procedures described by the USGS (variously dated). Existing pumps were used to collect samples from domestic and production wells. Temporary, positive-displacement sample pumps were used to collect samples from monitoring wells. 
Field parameters including temperature, specific conductance, $\mathrm{pH}$ and alkalinity were measured in the field at the time of sample collection using calibrated thermometers and portable meters calibrated in the field prior to measurement. Dissolved oxygen also was measured in the field just prior to sample collection. Water samples for analyses of major ions, nutrients, and selected trace elements were pressure-filtered in the field using capsule filters that had a pore size of $0.45 \mu \mathrm{m}$. Samples for laboratory analysis of $\mathrm{pH}$ and specific conductance were not filtered. Most of the samples were collected in polyethylene bottles that were rinsed three times with sample water prior to filling. Samples for nutrient determinations were collected in dark, opaque polyethylene bottles and preserved on ice to inhibit bacterial growth. Samples for cation and selected trace-element concentrations were collected in acid-rinsed polyethylene bottles and preserved by acidifying the sample to a $\mathrm{pH}$ less than 2 using a 2-ml vial of concentrated ultrapure nitric acid. Additional details regarding sample collection are provided in Clark et al. (2012).

Water samples for major-ions, nutrients (including nitrite, nitrite plus nitrate, ammonia, ammonia plus organic nitrogen, phosphorus, and orthophosphorus) selected minor-ions (including bromide, fluoride, and iodide), and selected trace elements (including arsenic, barium, boron, iron, and manganese) were analyzed within respective holding times at the USGS National Water Quality Laboratory. Water samples for isotopic analyses (including the stable isotopes of oxygen and hydrogen, and tritium) were analyzed at the USGS Reston Stable Isotope Laboratory. Water samples for carbon and carbon-14 activities were analyzed under contract with the USGS by mass-spectroscopy and accelerator mass spectroscopy, respectively. Additional details regarding sample analyses are provided in Clark et al. (2012).

\section{Coupled well-bore flow and depth-dependent water-quality data collection}

Well-bore flow logs were collected under unpumped and pumped conditions from 15 existing production wells between 2005 and 2012 to determine depths where water entered long-screened production wells. These data were collected using several different techniques including: (1) commercially available impeller or vertical-axis velocity meter (also known as spinner tools; Hill 1990) (2) electromagnetic (EM) velocity meter (Paillet 2000), and (3) the tracer-pulse method (Izbicki et al. 1999). The vertical-axis and the EM velocity meters were used in wells where access tubes allowed meter deployment below the production pump or in wells where the production pump had been removed and a smalldiameter temporary pump had been installed for data collection. The tracer-pulse method was used for wells with in-place production pumps and limited access. Data collected from a well in the study area using each of the techniques compared favorably (Clark et al. 2012).
Flow logs collected from wells under pumped conditions were coupled with depth-dependent water-chemistry data (collected from discrete depths within these wells) to evaluate aquifer water quality using techniques described by Izbicki et al. (1999) and Izbicki (2004). In general, when using these techniques, the deepest sample is representative of the aquifer chemistry at that depth. The next deepest sample is a mixture of water from the deepest sample and water that entered the well between the two sample depths. The mixture proportion can be resolved using flow $\log$ data to estimate the quality of water that entered the well between sample depths. Sample collection and interpretation generally proceeds in this fashion upward through the well to the shallowest sample.

\section{Sequential electromagnetic logging}

Aquifer water-level and water-chemistry data collected from monitoring wells are limited by the length of the well screen. In complex heterogeneous alluvial aquifers, shortscreened monitoring wells leave a large portion, up to $90 \%$, of the aquifer thickness unsampled (Metzger and Izbicki 2012). EM logs are sensitive to aquifer lithology and fluid resistivity, and can be collected through PVCcased monitoring wells over the entire length of the well casing within both screened and unscreened sections. Because aquifer lithology remains constant through time, EM logs collected at different times from the same well (sequential logs) provide information on depth-dependent changes in groundwater quality within an aquifer, which can aid in the identification of zones of changing water quality in intervals not sampled by well screens (Williams et al. 1993; Metzger and Izbicki 2012). EM data collected from screened intervals can also be compared to waterquality data collected from these screened sections for comparison.

Sequential EM logs were collected from the deepest accessible monitoring wells at eight multiple-well sites in the study area in April 2012 using methods described by Metzger and Izbicki (2012). Data were normalized to correct for difference from the initial calibration and were compared to previously published data collected between 2004 and 2008 (Metzger and Izbicki 2012) to estimate changes in groundwater chemistry since that time. Data were also compared to water-quality samples collected from monitoring wells at the same sites.

\section{Results}

\section{Test drilling, well installation, and water-level monitoring}

Alluvial deposits encountered during test drilling in the Eastern San Joaquin Groundwater Subbasin are heterogeneous, generally consisting of alternating layers of sand, silt, or clay. The lithologic logs for multiple-well sites 11H4-8 (STK-2) and 3D2-5 (STK-7, Figs. S1 and S2 of the ESM) are typical of wells drilled within the study area. Materials encountered during test drilling were generally 
of felsic/granitic origin, although increasing mafic minerals were encountered at depth in several boreholes, including 3D2-5 at depths greater than about $100 \mathrm{~m}$ (Fig. S2 of the ESM) and 11H4-8 at depths greater than about $175 \mathrm{~m}$ (Fig. S1 of the ESM). Thick coarse-grained deposits (sands and gravels) were encountered in most monitoring wells between $\sim 40$ and $60 \mathrm{~m}$ below land surface.

Water-level differences with depth at a single monitoring site were as large as $4-5 \mathrm{~m}$, consistent with some degree of confinement in deeper aquifer material by discontinuous fine-textured alluvial deposits. Overall, water levels show seasonal fluctuations, with maximum declines in the summer months of greater than $4 \mathrm{~m}$ when groundwater pumping is greatest. Although gradients were generally downward, at monitoring site 11H4-8 (STK-2) the depth to water in the deepest well $(11 \mathrm{H} 4)$ was shallower than the next shallowest well $(11 \mathrm{H} 5)$, indicating the potential for upward hydraulic gradients at depth. Deeper wells at this site did not directly exhibit short responses to nearby pumping observed in shallower wells and were isolated from nearby recharge (Fig. S3 of the ESM). Water levels at site 11H4-8 (STK-2) declined to their lowest levels in 2008-2009, with a recovery (on the order of about $0.5 \mathrm{~m}$ ) through the end of 2012. Waterlevel hydrographs for sites 11H4-7 and 3D2-5 are shown in Figs. S3 and S4 of the ESM; additional water-level hydrographs are available in Clark et al. (2012) and Metzger et al. (2012), and water-level data are available at the USGS National Water Information System Web page (2015).

\section{Water-chemistry and isotopic data}

Water from more than 200 domestic, production, and monitoring wells collected between 2003 and 2012 was slightly acidic to alkaline with pH's ranging from 6.5 to 9.8. Water was fresh to moderately saline, with dissolved solids concentrations ranging from 93 to $6,290 \mathrm{mg} / \mathrm{L}$. High salinity and dissolved-solids concentrations were associated with high-chloride concentrations. Chloride concentrations were as high as $2,050 \mathrm{mg} / \mathrm{L}$ in water from multiple-well site 2 N/5E-1A2-6 (1A2-6; STK-1) near the San Joaquin Delta. Groundwater was generally oxic, with dissolved oxygen concentrations typically greater than $0.5 \mathrm{mg} / \mathrm{L}$; however, deeper groundwater and groundwater near the San Joaquin Delta was reducing with dissolved oxygen concentrations less than $0.5 \mathrm{mg} / \mathrm{L}$. Reducing conditions within the aquifer contributed to arsenic concentrations greater than the US EPA maximum contaminant level (MCL) of $10 \mu \mathrm{g} / \mathrm{L}$ in about one-third of sampled wells in the subbasin (Izbicki et al. 2008).

\section{Chemical composition of water}

The major-ion composition of water from wells was evaluated using a trilinear diagram (Piper 1945). The diagram shows the proportions of the major cations (calcium, magnesium, and sodium plus potassium) and the major anions (carbonate plus bicarbonate, sulfate, and chloride) on a charge-equivalent basis. Cations are plotted on the lower left triangle, anions on the lower right triangle, and the central diamond integrates the data (Fig. 3). On the basis of their distribution within the trilinear diagram, data were aggregated into three groups having different chemical compositions. The groups are similar to those identified in the study area by Izbicki et al. (2006).

Group 1 (Fig. 3) is composed of calcium bicarbonate to mixed cation/anion waters having chloride concentrations less than the USEPA SMCL $250 \mathrm{mg} / \mathrm{L}$. Group 1 includes the majority of sampled domestic, production, and monitoring wells. Group 1 samples tend be oxic with a moderately alkaline $\mathrm{pH}$. Nitrate concentrations in group 1 are generally greater than those in groups 2 or 3, although most are below the USEPA MCL for nitrate $(10 \mathrm{mg} / \mathrm{L}$ as nitrogen, Fig. 4).

Group 2 (Fig. 3) is composed of sodium bicarbonate to mixed anion water having chloride concentrations less than the USEPA SMCL $250 \mathrm{mg} / \mathrm{L}$. Water having this composition is typical of groundwater in deep alluvial aquifers elsewhere in California as a result of precipitation of calcite and (or) exchange of calcium and magnesium for sodium on clay minerals as groundwater moves through aquifer deposits (Izbicki et al. 1991, 1996, 2003). Group 2 samples tend to have low dissolved oxygen concentrations with a moderately alkaline $\mathrm{pH}$ (median=8). Consistent with generally low dissolved oxygen concentrations and more reduced conditions, nitrate concentrations in group 2 are low, with a median concentration of less than $2 \mathrm{mg} / \mathrm{L}$ as $\mathrm{N}$ (Fig. 4).

Group 3 (Fig. 3) is composed of calcium-chloride to sodium-chloride waters; the majority of samples within

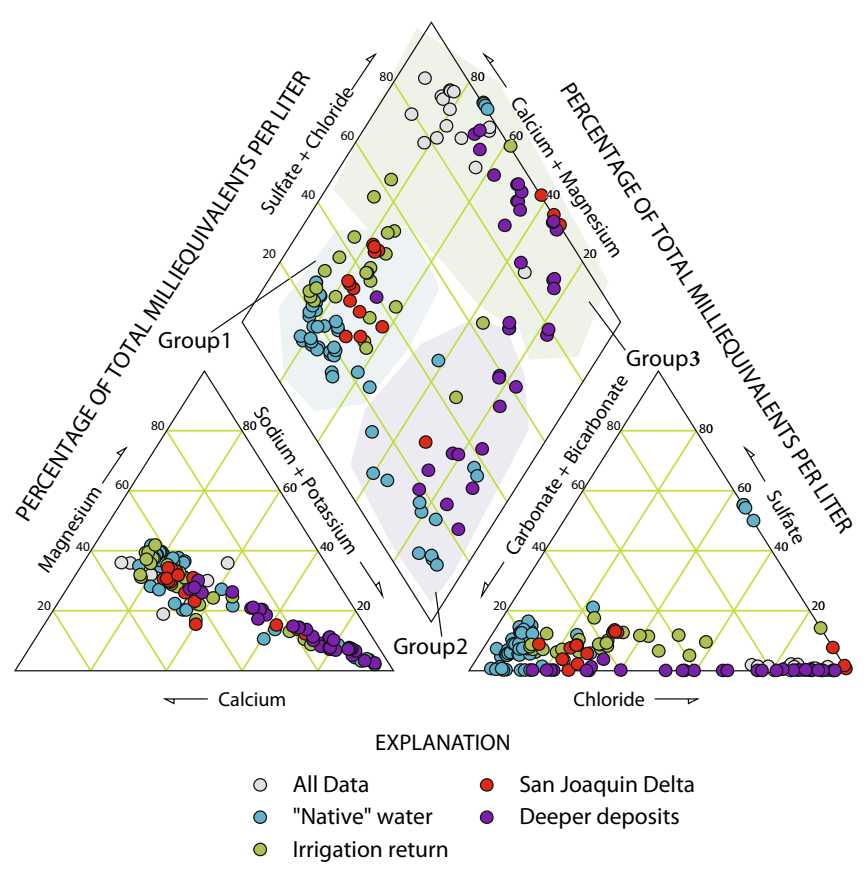

Fig. 3 Major-ion chemistry of water from selected wells in the Eastern San Joaquin Groundwater Subbasin 


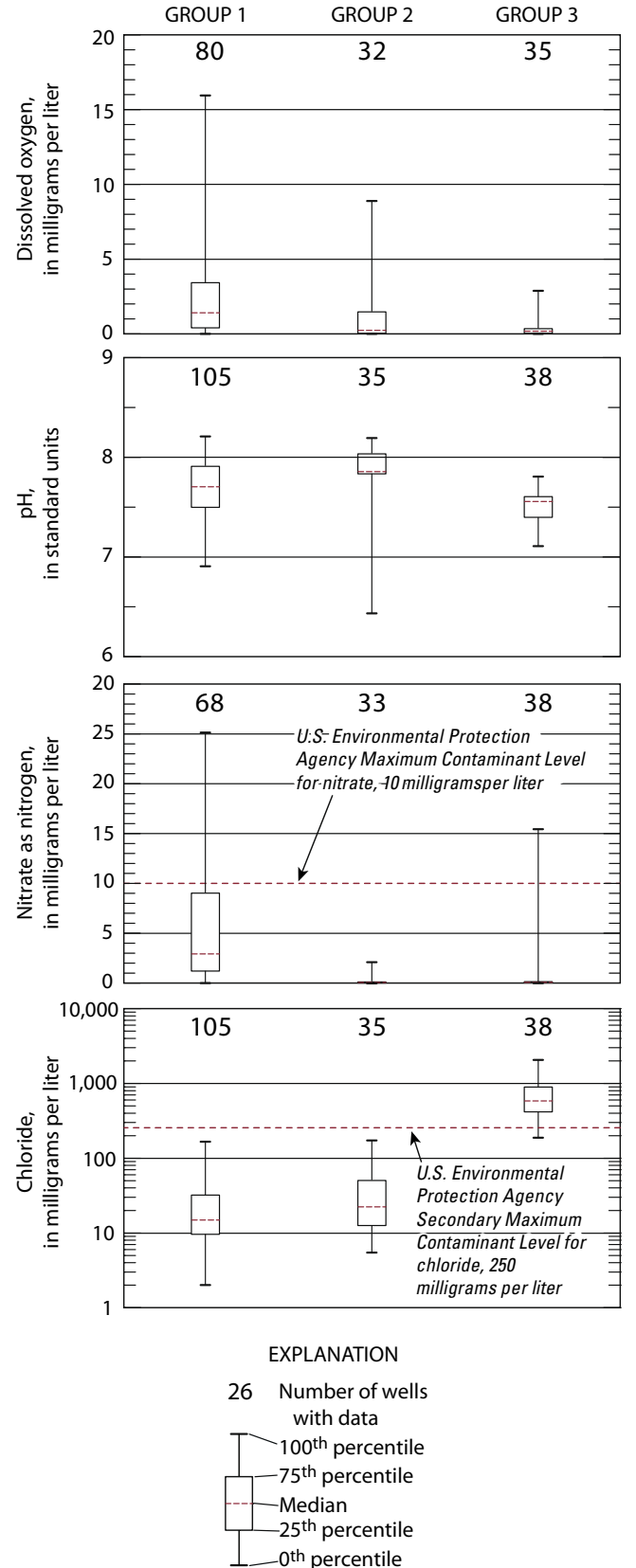

Fig. 4 Dissolved oxygen, $\mathrm{pH}$, nitrate, and chloride data from selected wells

this group have chloride concentrations greater than the USEPA SMCL of $250 \mathrm{mg} / \mathrm{L}$ (Fig. 4). Water having this composition is typical of groundwater in alluvial aquifers intruded by seawater elsewhere in California as a result of exchange of sodium for calcium and magnesium on clay minerals within aquifer deposits as chloride concentrations increase (Izbicki et al. 1991, 2003). Group 3 includes high-chloride samples ranging from 290 to $2,050 \mathrm{mg} / \mathrm{L}$ from monitoring wells at multiple-well sites 1A2-6 (STK1) and 1 N/6E-4 J3-5 (4 J3-5; STK-4) near the San Joaquin Delta. Group 3 also includes several publicsupply wells that have been removed from service due to chloride concentrations greater than the SMCL of $250 \mathrm{mg} /$
L. Group 3 has the lowest dissolved oxygen concentrations of the three groups, with a slightly alkaline $\mathrm{pH}$ (median=7.6). Nitrate concentrations in group 3 are low; iodide concentrations in group 3 tend to be much greater than the other groups. High-chloride water from marine rock and deep oilfield brine sampled elsewhere in California has a major-ion composition similar to group 3 (Izbicki 1996).

Statistical comparisons of chloride, nitrate, dissolved oxygen, $\mathrm{pH}$, and iodide between the groups were performed on the basis of the Median Test (Neter and Wasserman 1974). All constituents are statistically different between groups 1,2, and 3 at a confidence criterion of $\alpha=0.05$, except chloride from groups 1 and 2 and $\mathrm{pH}$ from groups 2 and 3 , which is not statistically different.

\section{Delta-oxygen-18 and delta deuterium data}

Oxygen-18 $\left({ }^{18} \mathrm{O}\right)$ and deuterium (D) are naturally occurring stable isotopes of oxygen and hydrogen, respectively. Oxygen-18 and deuterium contain more neutrons and have a greater atomic mass than atoms of the more abundant isotopes, oxygen-16 and hydrogen. Oxygen and hydrogen isotopic abundances are expressed as ratios of the heavy isotope to the lighter isotope, in delta $(\delta)$ notation, as per mil (part per thousand difference; \%o) relative to Vienna Standard Mean Ocean Water (VSMOW; Gonfiantini 1978). The difference in atomic weight results in differences in the physical and chemical behavior of water molecules containing the heavier isotopes compared to the lighter isotopes.

Most of the world's precipitation originates from the evaporation of seawater. As a result, the $\delta^{18} \mathrm{O}$ and $\delta \mathrm{D}$ composition of precipitation and most groundwater is linearly correlated and distributed along a line known as the global meteoric water line (Craig 1961). The $\delta^{18} \mathrm{O}$ and $\delta \mathrm{D}$ composition of a water sample relative to the meteoric water line and relative to the composition of water from other areas can provide a record of the source and evaporative history of the water. For example, isotopic values of precipitation and runoff become more negative and contain less of the heavier isotope (isotopically lighter) with increasing altitude (Ingraham and Taylor 1991; Friedman et al. 1992). In the study area, water that originated as precipitation that condensed at lower temperatures and fell at the higher altitudes of the Sierra Nevada are isotopically lighter (more negative) than water that condensed as precipitation at higher temperatures and fell at lower altitudes along the foothills of the Sierra Nevada, which contains more of the heavier isotope (isotopically heavier or less negative). The $\delta^{18} \mathrm{O}$ and $\delta \mathrm{D}$ composition of water that has been partly evaporated has been altered by a process known as fractionation and plots to the right of the global meteoric water line along an evaporative trend line.

The $\delta^{18} \mathrm{O}$ and $\delta \mathrm{D}$ composition of water samples from domestic, production, and monitoring wells in the study area ranged from -6.3 to $-11.5 \%$ and -48 to $-84 \%$, respectively. Most samples plot parallel and slightly below the global meteoric water line along a local meteoric water 
line (LMWL) (Fig. 5). $\delta^{18} \mathrm{O}$ and $\delta \mathrm{D}$ values were more negative (lighter) in water from shallow wells near the Mokelumne and Stanislaus rivers, which originate at high altitudes and cooler temperatures in the Sierra Nevada (Fig. 6a). These wells generally have low chloride concentrations (Fig. 5). More negative values were also measured in water from shallower wells near groundwater recharge facilities at Morada Lane (11H4-8; STK-2) and Stockton East Water District (3D2-5; STK-7) that receive water from the larger rivers draining the higher altitudes of the Sierra Nevada. The $\delta^{18} \mathrm{O}$ and $\delta \mathrm{D}$ composition of water sampled from the shallowest well $(11 \mathrm{H}-8)$ at multiple-well site 11H4-8 (STK-2) near the Morada Lane recharge pond, ranged from -7.5 to -9.7 and -52 and $-70 \%$, respectively. The wide range in isotopic composition in this well reflects the range in compositions of water from different sources infiltrated through the recharge pond over time, including: locally derived stormflow (isotopically heavier), and water from the Mokelumne River draining the higher altitudes of the Sierra Nevada (isotopically lighter). The most negative sample was from well 3D5 (Fig. 5), the shallowest well at multiple-well site 3D2-5 (STK-7) near the Stockton East Water District recharge ponds, which receives water from the Stanislaus River. In general, deeper wells, wells affected by managed aquifer recharge, or wells having higher chloride may differ in $\delta \mathrm{D}$ values from the contour intervals (Fig. 6a).

In general, $\delta \mathrm{D}$ values were less negative (heavier) in water from wells along the eastern edge of the study area as a result of groundwater recharge originating from precipitation that condensed at the lower altitudes and

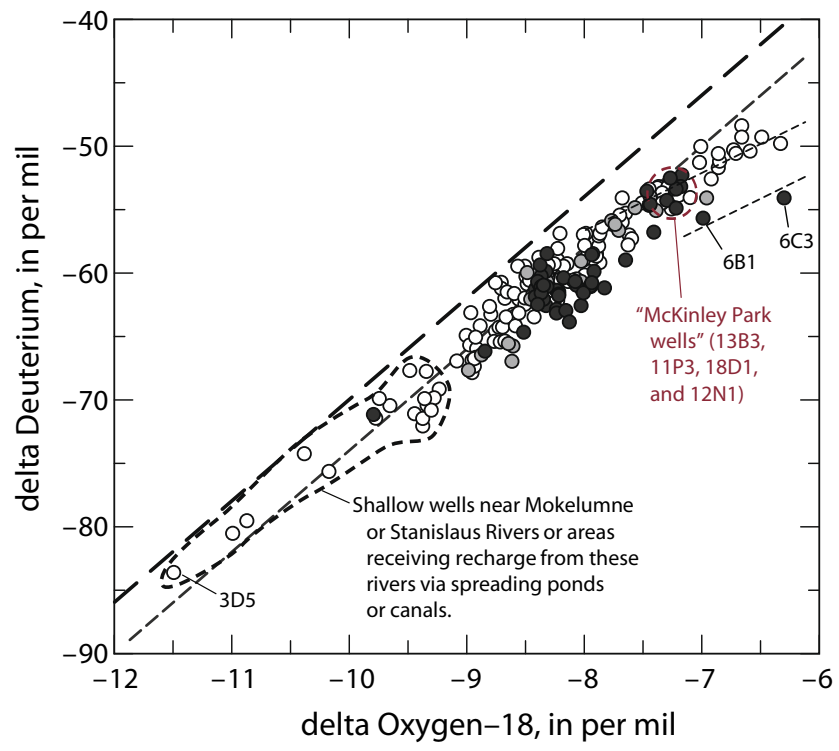

\section{EXPLANATION}

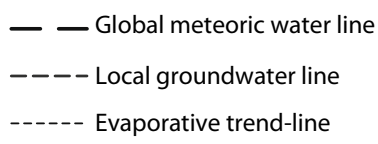

\begin{tabular}{|c|c|}
\hline 0 & $<100$ \\
\hline 0 & 100 to 250 \\
\hline 0 & $>250$ \\
\hline
\end{tabular}

Fig. 5 Delta oxygen-18 and delta deuterium composition of water from selected wells. Global meteoric water line after Craig 1961
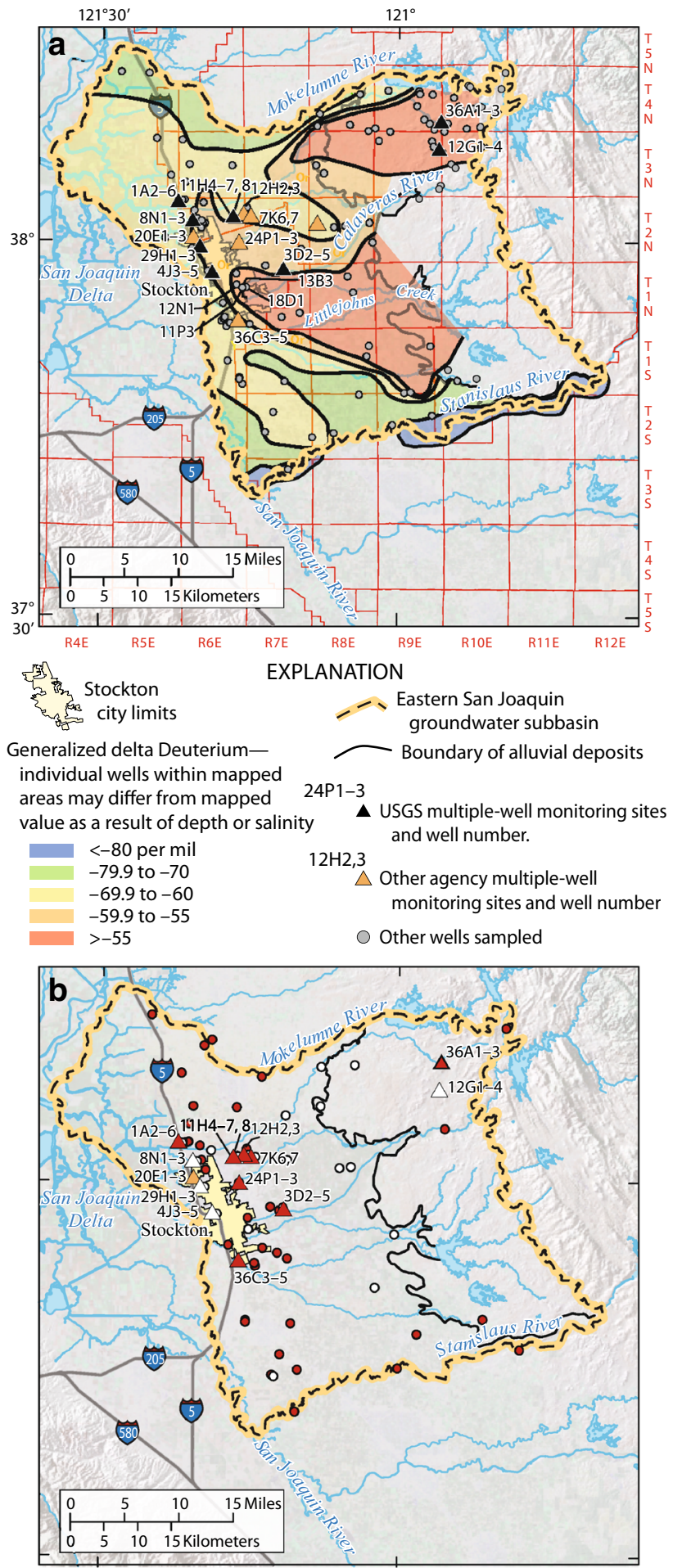

EXPLANATION

$\Delta$ Multiple-well monitoring site Tritium present in shallowest well

A Multiple-well monitoring site Tritium absent in shallowest well

$\triangle$ Multiple-well monitoring site Tritium data not collected

Other wells

Tritium present (picoCuries per liter $\geq 0.6$ )

$\bigcirc$ Tritium absent (picoCuries per liter $<0.6$ )

Fig. 6 Maps showing: a generalized delta deuterium concentrations; and b tritium data for selected wells, Eastern San Joaquin Groundwater Subbasin 
warmer temperatures near the foothills of the Sierra Nevada. Less negative values were also measured in samples plotting to the right of the Global Meteoric Water Line along apparent evaporative trend lines (Fig. 5). Although partial evaporation, including the presence of irrigation return water, may have increased chloride concentrations within these samples, concentrations do not generally exceed the SMCL for chloride of $250 \mathrm{mg} / \mathrm{L}$ (Fig. 5). The $\delta^{18} \mathrm{O}$ and $\delta \mathrm{D}$ compositions of water from wells near the San Joaquin delta having chloride concentrations greater than the SMCL range between about -8.8 to -7.6 and -66 to -59 , respectively (Fig. 5). Highchloride water from shallow wells in this area, $2 \mathrm{~N} / 6 \mathrm{E}-$ $6 \mathrm{~B} 1$ and $2 \mathrm{~N} / 6 \mathrm{E}-6 \mathrm{C} 3$, also may have been partly evaporated. In contrast, some high-chloride water from wells in south Stockton in the vicinity of McKinley Park (wells 1 N/7E-13B3, 1 N/7E-11P3, 1 N/7E-18D1, and $1 \mathrm{~N} / 6 \mathrm{E}-12 \mathrm{~N} 1$ ), have $\delta^{18} \mathrm{O}$ and $\delta \mathrm{D}$ compositions between about and -7.4 to -7.1 and -55 to -53 , respectively (Figs. 5 and 6a)-possibly reflecting a different source of water that may be related to historical gas development in this area.

\section{Tritium and carbon-14 data}

Tritium and carbon-14 data were collected from selected domestic, production, and monitoring wells in the study area (Clark et al. 2012). Tritium, a radioactive isotope of hydrogen having a half-life of about 12.3 years, was used to indicate the presence of more recently recharged groundwater, whereas carbon-14 data were used to indicate the presence of older groundwater.

Tritium activities are reported in picoCuries per liter $(\mathrm{pCi} / \mathrm{L}) ; 1 \mathrm{pCi} / \mathrm{L}$ is equivalent to about 2.2 disintegrations of tritium per minute or about one tritium atom in $2.1 \times 10^{17}$ atoms of hydrogen or about 0.31 tritium units. Although naturally occurring, tritium in the environment was increased as a result of atmospheric testing of nuclear weapons between 1952 and 1963 (Solomon and Cook 1999). For the purpose of this study, water that does not contain measurable tritium activity was recharged prior to 1952 (tritium absent) and water containing measureable tritium activity was recharged after 1952 (tritium present).

Tritium activities in water from sampled wells ranged from less than the reporting level of $0.6-46.7 \mathrm{pCi} / \mathrm{L}$. Tritium activities were greater than the reporting level in 29 of 53 wells sampled, and were widely distributed throughout much of the study area (Fig. 6b). Tritium was generally present in shallower wells (about $70 \mathrm{~m}$ depth) and generally absent in deeper wells at multiple-well sites (Fig. 7a); however, tritium was present at multiple-well site 2 N/6E-24P1-3 (24P1-3; Blossom Ranch) at depths greater than $150 \mathrm{~m}$ below land surface (Fig. 7a). Multiplewell site $24 \mathrm{P} 1-3$ is about $75 \mathrm{~m}$ north of production well $\mathrm{N} 2 / 6 \mathrm{E}-24 \mathrm{P} 4$ (24P4), having a capacity of $8.3 \mathrm{~m}^{3} / \mathrm{min}$ (Clark et al. 2012). Pumping from well 24P4, and subsequent downward gradients, may have induced or enhanced infiltration from adjacent surface water to depth within the aquifer. Similarly, tritium was present at multiple-well site 11H4-8 (STK-2) near the Morada Lane

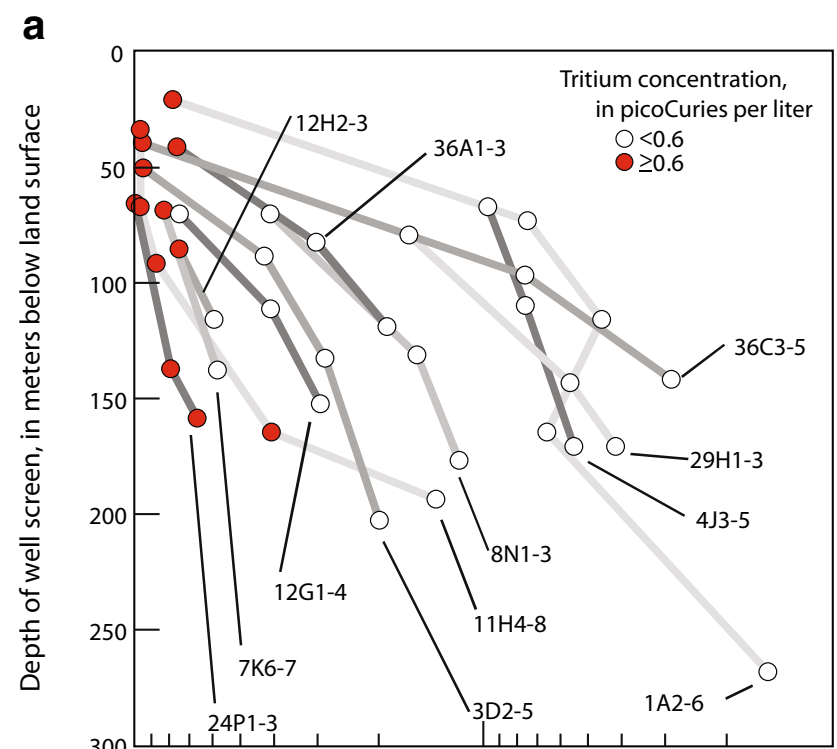

b

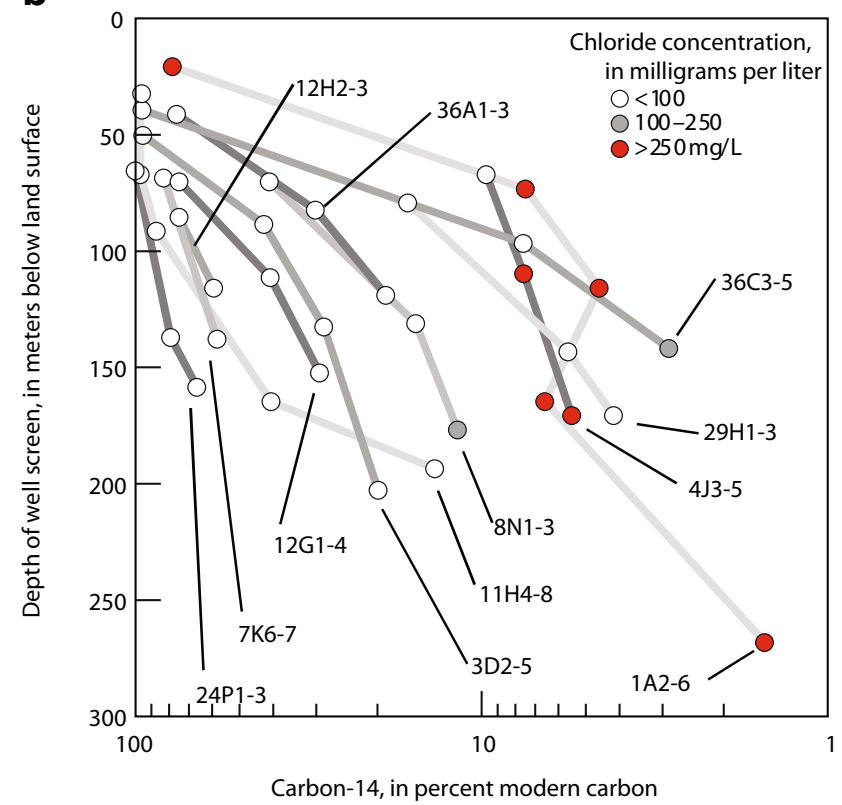

Fig. 7 Concentration of percent modern carbon with respect to depth and a tritium or $\mathbf{b}$ chloride concentrations from selected monitoring wells

recharge pond to a depth of $91 \mathrm{~m}$, suggesting that groundwater recharge at this site and nearby pumping have allowed water to infiltrate to greater depth within the aquifer (O’Leary et al. 2012).

Tritium was generally absent in wells constructed in alluvial deposits in the eastern part of the study area (Fig. 6b). The general absence of tritium in this part of the subbasin suggests that groundwater is generally older, and (1) focused recharge from smaller streams in this part of the study area is small compared to recharge along the larger rivers draining the Sierra Nevada, and (2) areal recharge from precipitation (large-scale irrigated agriculture is generally absent in this part of the subbasin) is small compared to recharge from irrigation 
return elsewhere in the subbasin. Additionally, these wells situated in the eastern part of the study area do not generally have increased chloride or nitrate concentrations, especially compared to the wells situated in the western part of the study area.

Carbon-14 is a radioactive isotope of carbon having a half-life of about 5,730 years, and is reported as percent modern carbon (pmC), where 13.56 disintegrations per minute per gram of carbon equals $100 \%$ modern carbon (pmC; Kalin 2000). Carbon-14 activities can approach, or exceed, $100 \mathrm{pmC}$ for recently recharged water containing tritium. Carbon-14 activities are lower for older groundwater isolated from the atmosphere for long periods of time. For example, neglecting reactions between water and aquifer minerals, water having a carbon-14 activity of $50 \mathrm{pmC}$ has been isolated from the atmosphere for about one half-life, or about 5,730 years. Carbon-14 ages calculated based on carbon-14 activities presented in this report do not account for changes in carbon-14 activities resulting from chemical reactions or mixing and therefore would be considered uncorrected ages. In general, uncorrected calculated carbon-14 ages may be older than the actual ages of the water after correction, based on carbon-13 and tritium data.

Carbon-14 activities in water from sampled wells ranged from $\sim 1$ to $120 \mathrm{pmC}$. Carbon-14 activities were higher in water from shallower wells at multiple-well sites containing tritium than in other wells. Activities were higher at multiple-well site 11H4-8 (STK-2) near Morada Lane to a depth of about $165 \mathrm{~m}$ below land surface than in most other wells at similar depths. A plot of carbon-14 versus depth (Fig. 7a) yields a concave-down trend-line at most multiple well sites, with the exception of $11 \mathrm{H} 4-8$ (Morada Lane) and 24P1-3, which are concave-up, indicating that changes in groundwater age occur more abruptly, over shorter depth intervals, at these sites than at other sites, consistent with tritium data. At multiple well sites 2N/7E-7K6-7 (7K6-7) and 12H2-3 (12H2-3, Fig. 7a), situated about 2.5 and 1.5 miles east of Morada Lane, tritium was present in the shallower wells, and comparatively high carbon-14 activities were measured in the deeper wells in comparison with most wells at comparable depths; these signatures of relatively young water may indicate that recently recharged water from Morada Lane may have reached or could reach those sites more rapidly than would occur in most of the study area. In contrast, carbon-14 activities near the Stockton East recharge facilities at multiple-well site 3D2-5 (STK-7) exhibit a concave-down trend (Fig. 7a) and do not indicate infiltration of recently recharged water to depths below about $50 \mathrm{~m}$.

With the exception of the data from multiple-well sites 11H4-8, 7K6-7, and 12H2-3 near the Morada Lane recharge pond, carbon-14 activities generally decrease with distance from natural recharge areas along the front of the Sierra Nevada to discharge areas near the San Joaquin Delta. In general, carbon-14 activities were lower in deep wells within multiple-wells sites at the downgradient end of long flow paths through the aquifer such as 1N/6E-36C3 (36C3) and 1A2 (Fig. 7a). Carbon14 activities also tend to decrease away from the larger rivers draining the Sierra Nevada. Comparatively low carbon-14 activities and the absence of tritium indicate older uncorrected groundwater ages at sites in the western part of the study area and far from major rivers draining the Sierra Nevada. In these same areas, less negative $\delta \mathrm{D}$ and $\delta^{18} \mathrm{O}$ are consistent with a recharge source at the eastern edge of the subbasin from lower altitudes of the Sierra Nevada. The co-occurrence of old groundwater and low-altitude isotopic signatures suggests that the recharge rate along the eastern edge of the subbasin from lower altitudes within the Sierra Nevada is small compared to focused and areal sources of groundwater recharge elsewhere in the subbasin, particularly along rivers draining high altitude portions of the Sierra Nevada. In general, chloride concentrations also increased with groundwater age and position along the flow path as groundwater approached the San Joaquin delta (Fig. 7b). The lowest pmC activity was in water from the deepest well, $268 \mathrm{~m}$ below land surface, at multiple-well site 1A26 (STK-1) near the San Joaquin delta.

In wells where tritium is absent, decreasing carbon-14 activities are generally associated with increasingly negative deuterium values, indicating that more negative (lighter) values correspond with older groundwater in these wells (Fig. 8). The data form a continuum from the eastern most multiple-well sites, 36A1-3 and 12G1-4, to the deep wells at the farthest downgradient sites, 1A2-6 (STK-1) to the north and 36C3-5 to the south (Figs. 1 and 8). This pattern is consistent with groundwater throughout much of the study area between the Stanislaus and

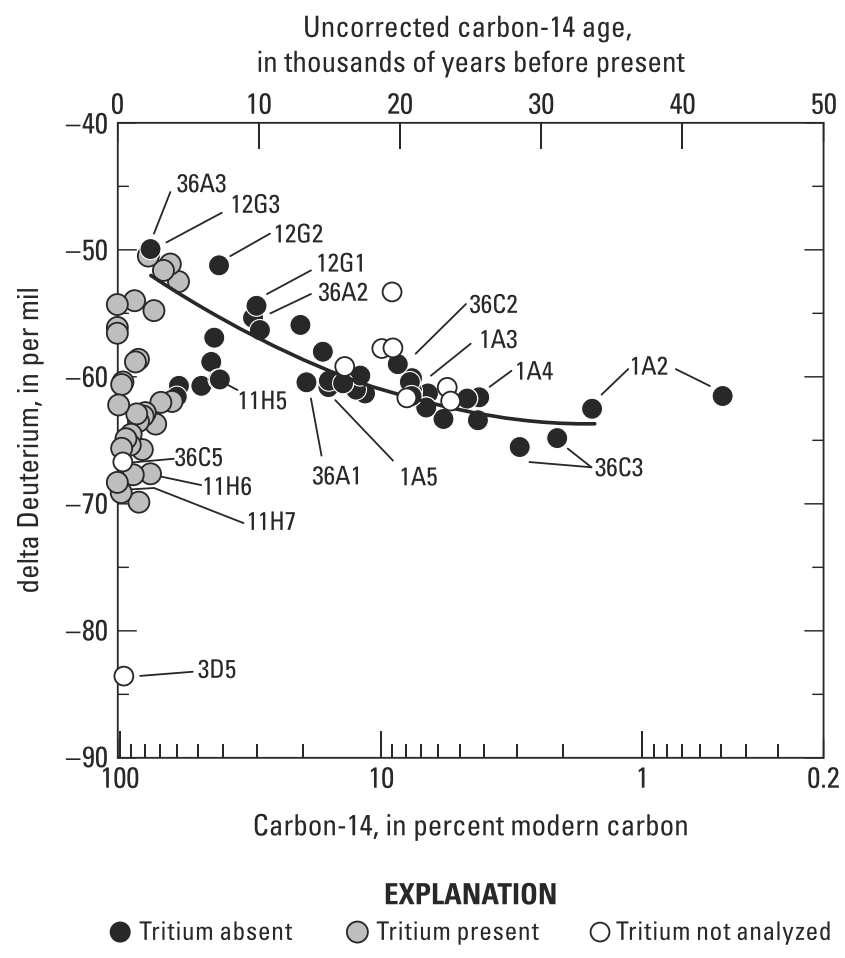

Fig. 8 Uncorrected carbon-14 age as a function of delta deuterium in water from selected monitoring wells 
Mokelumne rivers originating largely from recharge sources along the front of the Sierra Nevada near the eastern edge of the subbasin. Although the foothills of the Sierra Nevada are an important source of recharge to the study area, the low carbon-14 activities and older age of this water suggests that recharge rates in these areas between and distal to the rivers are low when compared to areas receiving recharge from the major rivers draining the Sierra Nevada. One possible explanation for the changes in $\delta \mathrm{D}$ composition with groundwater age is that the recharge area may have been subjected to increasingly warmer (and possibly drier) climatic conditions during recent geologic time. In tritium-absent waters, there is a change in $\delta D$ values of about $-15 \%$ with increasing groundwater age, from about $-50 \%$ in waters with higher carbon-14 activities (younger) to about $-65 \%$ in waters with lower carbon-14 activities (older). Given this range in $\delta \mathrm{D}$ values and an altitude effect of $-40 \% / 1,000 \mathrm{~m}$ in the Sierra Nevada (Friedman and Smith 1970, 1972), conditions in groundwater recharge areas in the foothills of the Sierra Nevada when the oldest groundwater was recharged would be similar to present-day conditions $375 \mathrm{~m}$ higher in the Sierra Nevada if those waters were recharged in the same general location. These data suggest the possibility that groundwater recharge from the foothills of the Sierra Nevada may have decreased over recent geologic time. It is also possible that the older groundwater is a mixture of water recharged from the foothills of the Sierra Nevada and water recharged along the longitudinal axis of the San Joaquin River.

In wells where tritium is present, there is no relationship between $\delta \mathrm{D}$ values and carbon-14 activities, likely due to development of the subbasin and the varying sources of natural and artificial recharge to wells with detectable tritium concentrations; however, recently recharged water in wells $11 \mathrm{H} 6,11 \mathrm{H} 7,3 \mathrm{D} 5$, and $36 \mathrm{C} 5$ has more negative $\delta \mathrm{D}$ values than other sampled wells (Fig. 8). These are shallow wells and tend to be located close to sources of natural and artificial recharge that derive their water from the Mokelumne and Stanislaus rivers. No multiple-well sites were available along either the Stanislaus or Mokelumne rivers to directly assess changes in the isotopic composition of groundwater that was recharged from sources that originated from higher altitudes in the Sierra Nevada with groundwater age.

\section{Coupled well-bore flow and depth-dependent water- quality data}

Well-bore flow logs were collected for 11 production wells under unpumped and pumped conditions (Clark et al. 2012). Most wells in the study area yield water from comparatively thin layers encountered by the screened interval of the well. Unpumped and pumped well-bore flow data collected from production wells 1N/7E-4G1 (4G1) at the Stockton East recharge facilities in June 2012 and from production well $2 \mathrm{~N} / 6 \mathrm{E}-11 \mathrm{H} 3(11 \mathrm{H} 3)$ in June 2007 are typical of data collected in the study area (Figs. S5 and S6 of the ESM). Reported construction data for the well, including the depth of the screened interval, were confirmed on the basis of caliper, unpumped fluid resistivity, and unpumped fluid temperature logs, collected from the well but not shown in Figs S5 and S6 of the ESM. Unpumped flow through well 4G1 was downward at rates as high as $0.9 \mathrm{~L} / \mathrm{s}$ from the uppermost portions of the well screens (or perforations) between 61 and $68 \mathrm{~m}$ bls to the producing zones at greater depth within the aquifer. Under pumping conditions, large portions of the flow to well 4G1 were contributed through two relatively thin intervals from 61 to 68, and from 94 to $100 \mathrm{~m}$ bls (Fig. S5 of the ESM). These two intervals, comprising $14 \%$ of the screened interval, yield approximately $66 \%$ of the flow to the well.

Similar to well 4G1 under pumped conditions, most logged production wells within the study area also produced large percentages of their yield from relatively thin intervals (heterogeneous flow), with some wells such as $31 \mathrm{C} 1$, yielding up to half of their flow from less than $10 \%$ of their screened interval (Clark et al. 2012). The minimum length of screen (as a percentage of total screen length) to generate 25,50 , and $75 \%$ of the total flow contribution under pumping conditions was evaluated for each of the 11 pumped wells (Fig. 9). Three wells, 1N/7E4G1 (4G1), 1N/7E-31C1 (31C1), and 2N/6E-27 L1 $(27 \mathrm{~L} 1)$, produced $25 \%$ of their yield from less than $5 \%$ of their screened interval. Most wells produce $50 \%$ or more of their yield from $35 \%$ or less of their screened interval, and only two wells (2N/6E-4Q1 and 1N/7E-8H2) have fairly uniform distributions of flow producing about $50 \%$ of their flow from about half their screened interval (Fig. 9).

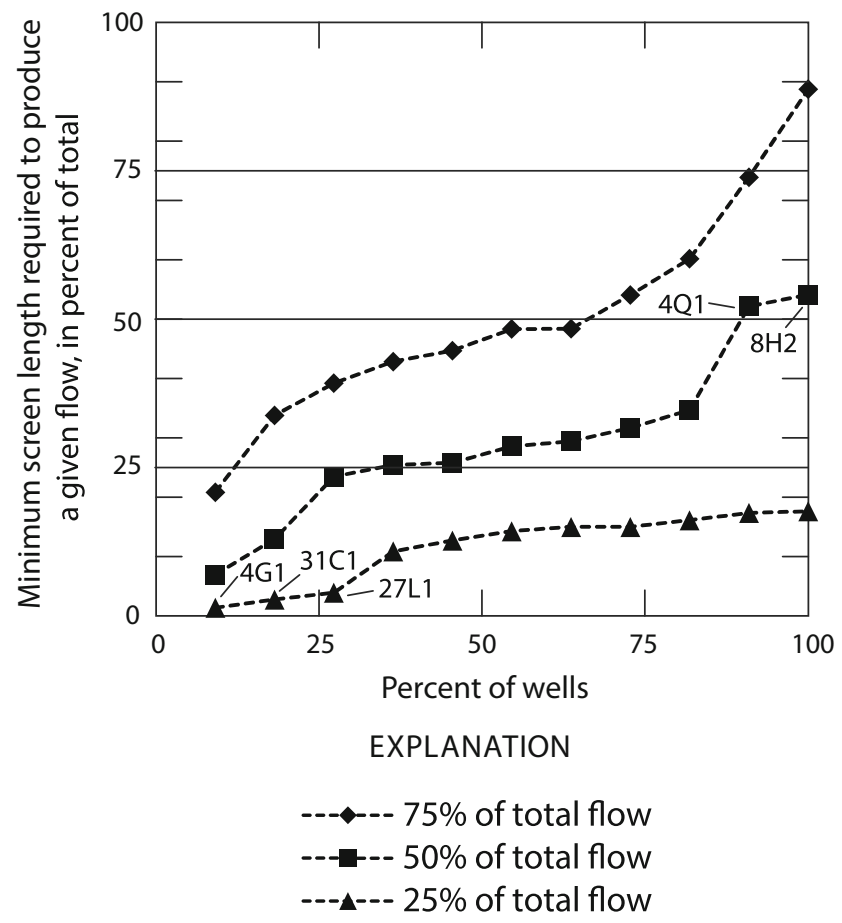

Fig. 9 Minimum percentage of overall screen length required to produce 25,50 , or $75 \%$ of overall flow from selected wells 
Heterogeneity plays an important role in the movement of recharge water to wells as more permeable, interconnected deposits can rapidly move water horizontally from recharge facilities to supply wells (Izbicki et al. 2010; O'Leary et al. 2012). In areas where long residence times within aquifers are required to meet regulatory requirements intended to protect public health, high-groundwater flow velocities and short travel times to nearby publicsupply wells resulting from aquifer heterogeneity may limit recharge using water of impaired quality (O'Leary et al. 2012). Conversely, heterogeneous deposits with laterally extensive confining layers may inhibit surface recharge from reaching screened sections of nearby production wells. Heterogeneity also plays an important role in the suitability of a well for modifications to improve water quality if intervals of high flow contribution are also of high quality. Izbicki et al. (2008) documented a reduction in arsenic concentrations in well $20 \mathrm{~N} 1$ after sealing off the deepest wells screens where depth-dependent water-quality data indicated higher arsenic concentrations. A measure of the relative heterogeneity of flow contributed to wells as a percentage of the total yield $(25,50$, and $75 \%)$ was calculated using the following equation:

Heterogeneity flow factor $=\left|\log \left(\frac{\text { percent of screen length contributing to a given flow }}{\text { percent of flow contributed by the screen length }}\right)\right|$

Smaller values (approaching a minimum of zero) are interpreted as more homogeneous flow, while values greater than zero (approaching a maximum of 1) are interpreted as increasingly heterogeneous flow (Table 1). For example, a well with $50 \%$ of the flow contributed over $50 \%$ of the screen (homogeneous flow) would result in a value of zero, whereas a well with $10 \%$ of the flow contributed over $90 \%$ of the screen or $90 \%$ of the flow over $10 \%$ of the screen (heterogeneous flow) would result in a heterogeneity flow factor of 0.95 . The rankings for each well differed depending on the flow percentage evaluated $(25,50$, or $75 \%)$, and an average of the three

Table 1 List of wells with well-bore flow and/or depth-dependent water-quality data, Eastern San Joaquin subbasin, California, 20052012

\begin{tabular}{|c|c|c|c|}
\hline State ID $^{\mathrm{a}}$ & Log type & $\operatorname{Date}(\mathrm{s})^{\mathrm{b}}$ & $\begin{array}{l}\text { Average } \\
\text { heterogeneity } \\
\text { flow factor }^{\mathrm{c}}\end{array}$ \\
\hline $1 \mathrm{~N} / 7 \mathrm{E}-31 \mathrm{C} 1$ & $\mathrm{U}, \mathrm{P}$ & $3 / 2007,3 / 2008$ & 0.79 \\
\hline 1N/7E-4G1 & $\mathrm{U}, \mathrm{P}$ & $4 / 2012$ & 0.64 \\
\hline 2N/6E-27L1 & $\mathrm{P}$ & $2 / 2005$ & 0.56 \\
\hline $2 \mathrm{~N} / 6 \mathrm{E}-11 \mathrm{H} 3$ & $\mathrm{U}, \mathrm{P}$ & $3 / 2007,6 / 2007$ & 0.24 \\
\hline 2N/6E-12J1 & $\mathrm{U}, \mathrm{P}$ & $5 / 2006,8 / 2006$ & 0.23 \\
\hline $2 \mathrm{~N} / 6 \mathrm{E}-24 \mathrm{P} 4$ & $\mathrm{U}, \mathrm{P}$ & $\begin{array}{l}8 / 2004,2 / 2005 \\
1 / 2006\end{array}$ & 0.22 \\
\hline $2 \mathrm{~N} / 6 \mathrm{E}-5 \mathrm{~F} 1$ & $\mathrm{U}, \mathrm{P}$ & $8 / 2004,2 / 2005$ & 0.20 \\
\hline 2N/6E-1Q1 & $\mathrm{U}, \mathrm{P}$ & $1 / 2006,8 / 2006$ & 0.20 \\
\hline $1 \mathrm{~N} / 7 \mathrm{E}-20 \mathrm{~N} 1$ & $\mathrm{U}, \mathrm{P}$ & $8 / 2004,7 / 2005$ & 0.15 \\
\hline 2N/6E-4Q1 & U, P & $6 / 2005,7 / 2005$ & 0.13 \\
\hline $1 \mathrm{~N} / 7 \mathrm{E}-8 \mathrm{H} 2$ & $\mathrm{P}$ & $2 / 2005$ & 0.11 \\
\hline 1N/7E-28F1 & $\begin{array}{l}\text { No log, } \\
\text { sampled } \\
\text { only }\end{array}$ & $7 / 2005$ & - \\
\hline $1 \mathrm{~N} / 6 \mathrm{E}-04 \mathrm{P} 2$ & $\mathrm{U}$ & $2 / 2005$ & - \\
\hline $1 \mathrm{~N} / 6 \mathrm{E}-12 \mathrm{~A} 1$ & U & $2 / 2005$ & - \\
\hline $3 \mathrm{~N} / 6 \mathrm{E}-10 \mathrm{~A} 1$ & $\mathrm{U}$ & $2 / 2005$ & - \\
\hline
\end{tabular}

${ }^{\text {a }}$ California State Well Numbering System identification

${ }^{\mathrm{b}}$ Month/year that flow log was collected

${ }^{\mathrm{c}}$ See report text for explanation

$P$ well was logged under pumped conditions; Uwell was logged under unpumped conditions

Hydrogeology Journal (2015) 23: 1515-1533 was calculated for each well. Average heterogeneity flow factors for individual wells ranged from 0.11 to 0.79 (Table 1). While variability of aquifer materials has a large influence on well-bore flow within a well, heterogeneity may also be affected by other complex factors such as screen placement, annular fill, well development, and (or) scaling (Garcia et al. 2010). Aquifer heterogeneity also may facilitate movement of high-chloride water to pumping wells in the study area. Metzger and Izbicki (2012) used sequential electromagnetic log data to demonstrate rapid movement of highchloride water from sediments near the San Joaquin Delta to wells.

\section{Sequential electromagnetic logs}

Evaluation of sequential EM logs indicates that groundwater moves through thin permeable layers and that most changes in chloride concentration occur in these intervals. Metzger and Izbicki (2012) established a statistical relation between EM resistivity and chloride concentration of groundwater to estimate chloride concentrations in unscreened well intervals. Using this relation, EM logs collected through 2007 suggested movement of highchloride water from the delta through thin (between 1 and 7-m-thick intervals), hydraulically connected, permeable aquifer layers. Sequential EM logs showed higher chloride concentrations in these thin intervals in the northern part of the study area, near multiple-well sites 1A2-6 (STK-1) and 2N/6E-8 N1-3 (8N1-3; STK-5). Other areas (near multiple-well sites 2N/6E-29H1-3 (29H1-3; STK-6) and 2N/6E-20E1-3 (20E1-3; Swenson Park) showed improving water quality (decreasing chloride concentrations) possibly as a result of groundwater management in the subbasin (Metzger and Izbicki 2012).

Additional EM logs collected in the spring of 2012 are presented along a north-south transect in Fig. 10. The 2012 EM log evaluations also show groundwater-quality changes typically occur in thin, resistive, and coarser 
Distance, in kilometers

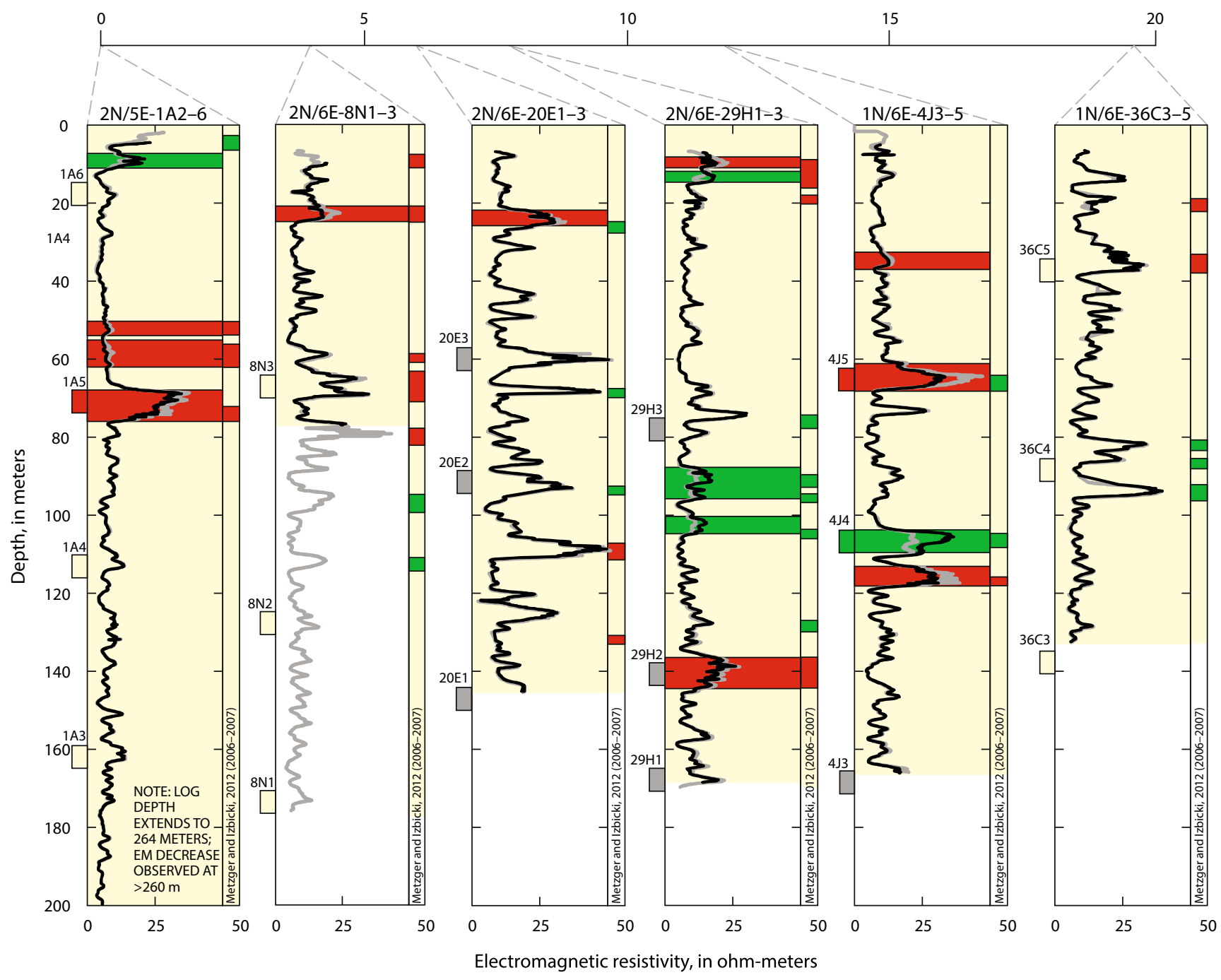

EXPLANATION

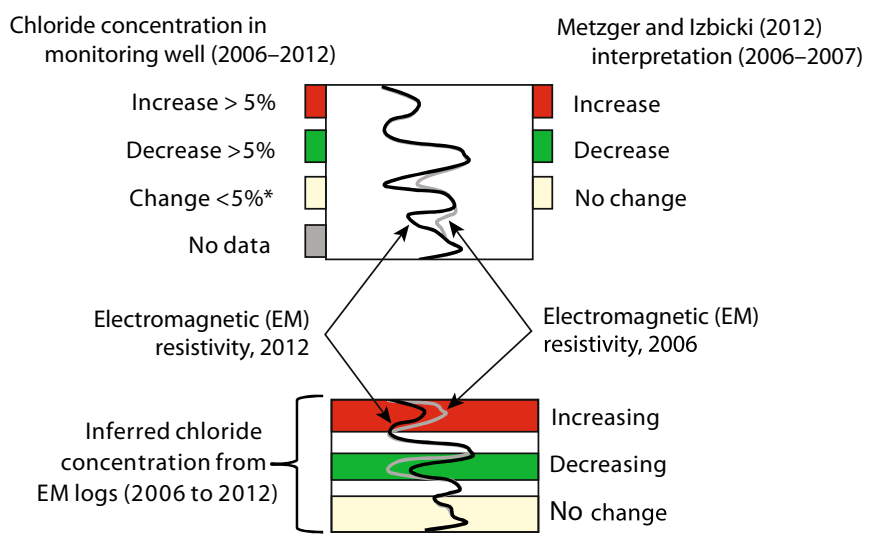

*Changes in concentration $<5$ milligrams per liter
included regardless of percentage change

Fig. 10 Sequential electromagnetic resistivity logs, and chloride concentrations for selected multiple-well sites (see Metzger and Izbicki 2012)

intervals with degrading groundwater quality to the north near site 1A2-6 (STK-1), little change in the central Hydrogeology Journal (2015) 23: 1515-1533 portion near sites 8N1-3 (STK-5), 20E1-3, and 29H1-3 (STK-6), and variable changes to the south, with site 4J3- 
5 (STK-4) showing generally degrading water quality and 36C3-5 showing little change.

Data collected from 4J3-5 (STK-4) shows a decrease in resistivity (degrading groundwater quality) in the vicinity of well 4J5 (screened at 61.0-67.1 m bls) and an increase in resistivity (improving groundwater quality) in the vicinity of well $4 \mathrm{~J} 4$ (screened at $103.6-109.7 \mathrm{~m}$ bls) between 2006 and 2012. There was also a decrease in resistivity (degrading groundwater quality) in an unscreened portion of the aquifer at a depth of about 113118 m (Fig. 10).

Changes in EM resistivity and changes in chloride concentrations in samples collected from monitoring wells were consistent in that increasing resistivity readings correlated with decreasing chloride concentrations and vice-versa. Continued water-quality degradation may be a result of continued stresses on aquifers, whereas logs collected through 2007 were collected under relatively wet/average climactic conditions, while drier conditions have been present in more recent years.

\section{Discussion}

As a result of pumping in excess of recharge, water levels in parts of the Eastern San Joaquin Groundwater Subbasin declined to below sea-level in the early 1950s (California Dept. of Water Resources 1967). Increasing chloride concentrations in groundwater supply wells has prompted water managers to evaluate and adopt management strategies to recharge aquifers, raise water levels, and control increasing chloride concentrations and to investigate the source(s) of chloride in groundwater.

\section{Sources of high-chloride water to wells}

Three primary sources of high-chloride water in the subbasin were identified from geologic, hydrologic, and geochemical data: (1) irrigation return water, (2) highchloride water from San Joaquin Delta sediments, and (3) high-chloride water from deep deposits. Some wells may yield high-chloride water that is a mixture of water from different sources. Trace element and minor ion data, including iodide, have been used to examine seawater intrusion and distinguish high-chloride water from sources other than seawater in alluvial aquifers elsewhere in California (Piper and Garrett 1953; Izbicki 1996; Jones et al. 1999; Izbicki et al. 2003, 2005). Chloride-to-iodide ratios as a function of chloride concentrations aggregate mixtures of water affected by different sources of chloride within the subbasin. The ratio of chloride to iodide is effective in distinguishing water from different sources because the addition of a small volume of water from sources having different compositions can produce a large change in the chloride-to-iodide ratio of water in a sample.

A plot of chloride-to-iodide ratios (Fig. 11a) shows representative source-water end-members having distinctive compositions. These mixtures, grouped by source are presented as box-plots in Fig. 11b. Chloride Hydrogeology Journal (2015) 23: 1515-1533
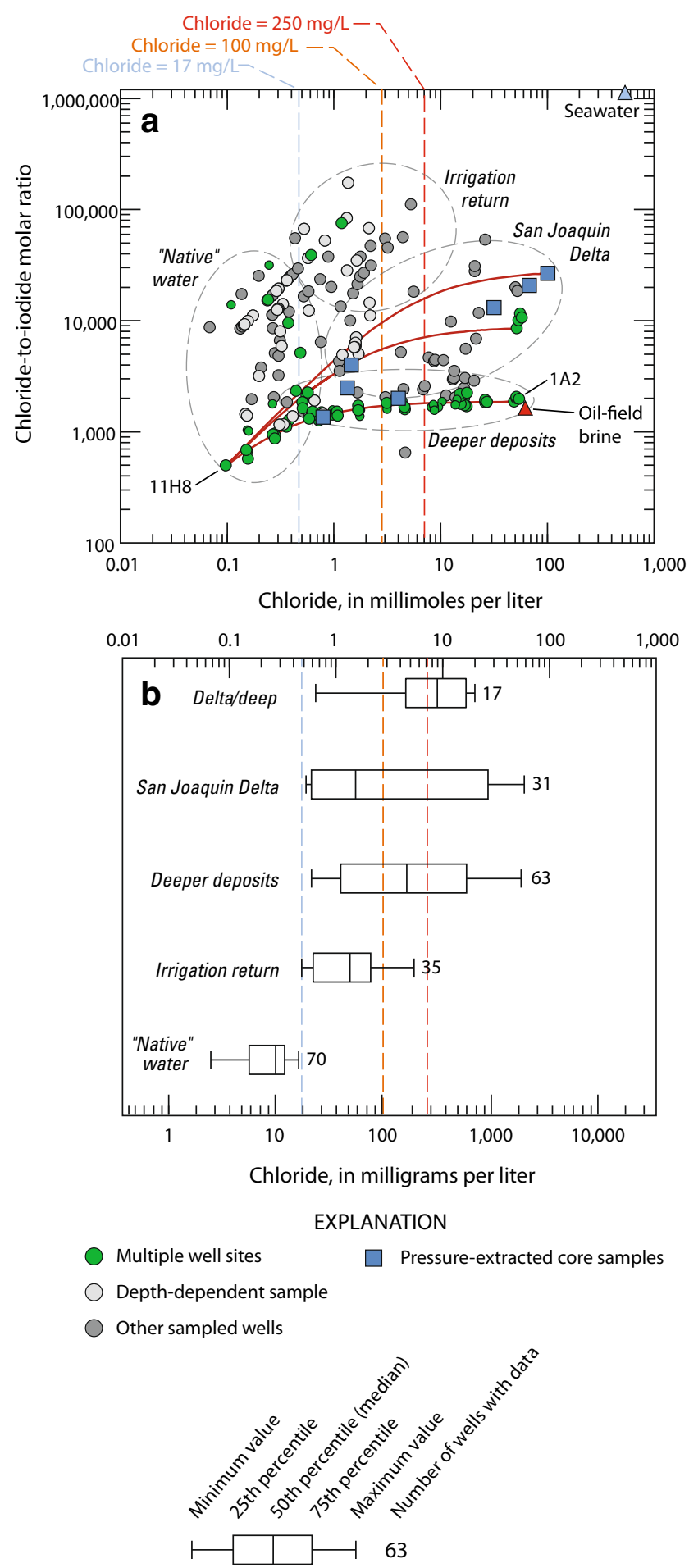

Fig. 11 Chloride-to-iodide ratio as a function of a chloride concentration; and $\mathbf{b}$ wells grouped by source

concentrations in water from sampled wells ranged from 2 to $2,050 \mathrm{mg} / \mathrm{L}$. Iodide concentrations ranged from less than the laboratory reporting level of 0.002 to $3.51 \mathrm{mg} / \mathrm{L}$. Native groundwater is represented by samples having $\delta^{18} \mathrm{O}$ and $\delta \mathrm{D}$ compositions showing minimal evaporative effects associated with irrigation return, chloride concentrations less than about $17 \mathrm{mg} / \mathrm{L}$ (Fig. 11b), and nitrate 
concentrations less than $5 \mathrm{mg} / \mathrm{L}$ as $\mathrm{N}$. Chloride-to-iodide ratios of native groundwater samples were variable. Native groundwater includes samples associated with recharge from the Sierra Nevada characterized by high chloride-to-iodide ratios typical of water in granitic terrains (Izbicki 1991). Irrigation return water is represented by samples from wells with shifts in $\delta^{18} \mathrm{O}$ and $\delta \mathrm{D}$ compositions consistent with partial evaporation, chloride concentrations as high as $198 \mathrm{mg} / \mathrm{L}$, nitrate concentrations as high as $25 \mathrm{mg} / \mathrm{L}$, and relatively high chloride-to-iodide ratios (Fig. 11a). High-chloride water from delta sediments is represented by water samples pressure-extracted from cores collected at depths ranging from 15 to $294 \mathrm{~m}$ bls during drilling at multiple well sites 1A2-6 (STK-1), 8 N1-5 (STK-5), and 29H1-3 (STK-6). Water extracted from core material has chloride concentrations ranging from 18.6 to $3,600 \mathrm{mg} / \mathrm{L}$ (Clark et al. 2012) and moderate to high chloride-to-iodide ratios. Most pressure-extracted samples plot along a LMWL, although those with the highest chloride concentrations plot along an evaporative trend line, which would be consistent with the emplacement of soluble salts in sediments by the evaporation of groundwater discharge along the aquifer margin under predevelopment conditions. The deep high-chloride groundwater end-member is represented by samples collected from the deepest monitoring well constructed as part of this study (well 1A2, screened from 262.1 to $268.2 \mathrm{~m}$ bls). The deep-groundwater (oil-field brine) endmember (Fig. 11a) differs from water pressure extracted from core material collected during drilling, and is similar in iodide and chloride composition to samples collected from marine rocks and deep oil-field brine sampled elsewhere in California (Izbicki 1996).

Chloride-to-iodide ratios indicate 35 sampled domestic and production wells (16\% of total wells sampled) contain irrigation return water, although none of these wells exceeded the SMCL. Chloride concentrations associated with San Joaquin Delta sources can exceed the SMCL, with at least 11 domestic and production wells (5\% of the total wells sampled) having chloride concentrations greater than $250 \mathrm{mg} / \mathrm{L}$. These wells are located along the western margin of the subbasin near the delta margin. The majority of domestic and production wells with chloride concentrations above the SMCL are associated with deep-water sources or mixtures of deepwater and/or delta water mixed with native groundwater (Fig. 11a) and are located in the southern portion of the study area near the historic regional pumping depression (Fig. 2a). Similar groupings occur in the trilinear diagram (Fig. 3) with low-chloride native water plotting as part of groups 1 and 2; San Joaquin Delta sources with chloride concentrations below and above the SMCL plotting as part of groups 1 and 3, respectively; and deeper sources with chloride concentrations below and above the SMCL plotting as part of groups 2 and 3, respectively.

Chloride to iodide ratios indicate that most highchloride concentrations in monitoring wells is related to deep-water sources, while high chloride concentrations in production wells tend to be a mixture of deep-water and/or delta-water sources mixed with native groundwater (Fig. 11a). Monitoring wells typically have short screen intervals (commonly about $7 \mathrm{~m}$ ) situated in coarser deposits and samples collected from monitoring wells may not necessarily be representative of water-quality changes affecting long-screened production wells, which are deriving water from both coarse- and fine-grained deposits. Metzger and Izbicki (2012) indicated that multiple-well monitoring sites constructed in the study area may sample only as much as $10 \%$ of the aquifer, leaving as much as $90 \%$ of the aquifer unsampled.

\section{Natural and managed recharge}

\section{Natural recharge}

East of Stockton, the distribution of groundwater with detectable tritium concentrations $(\geq 0.6 \mathrm{pCi} / \mathrm{L})$ roughly follows the axes of the Mokelumne and Stanislaus rivers (Fig. 6b) and generally coincides with the areas of isotopically lighter groundwater (Fig. 6a). Further, a large portion of groundwater east of Stockton, particularly the area located between these major rivers, is comprised of isotopically heavier groundwater ( $\delta \mathrm{D}$ compositions greater than -55 , Fig. 6a) that does not contain tritium. The presence of more recently recharged (younger) lighter groundwater in wells along the major rivers illustrates the significance of groundwater recharge originating as precipitation from the higher altitudes of the Sierra Nevada and infiltrated along losing stretches of these rivers. Although water recharged along the front of the Sierra Nevada accounts for much of the groundwater presently in storage within aquifers underlying the study area, recharge rates from this source are small relative to the river sources and may have declined in recent geologic time.

\section{Managed recharge}

Managed aquifer recharge presents an opportunity to supplement natural recharge, especially in areas not receiving recharge from the major rivers where presentday natural recharge from the front of the Sierra Nevada is low relative to the current and historic pumping of groundwater in the subbasin. The effect of managed aquifer recharge on water levels and water quality was investigated at two sites in the study area-Morada Lane and Stockton East. Multiple-well site 11H4-8 (STK-2; maximum depth of $194 \mathrm{~m}$ bls; Fig. 1) is located at the Morada Lane recharge facility adjacent to a 4-ha infiltration pond containing stormflow runoff from the nearby urban area and water from the Mokelumne River. The volume of water infiltrated at the site between 2003 and 2006 was about $3.3 \times 10^{6} \mathrm{~m}^{3}$ (Condor Earth Technologies 2006). Test-drilling data showed alluvial deposits consisting of interbedded gravel, sand, silt, and clay largely eroded from granitic rock to a depth of about $175 \mathrm{~m}$. The alluvium became increasingly consolidated with depth. These deposits overlie alluvium eroded largely 
from more mafic material extending to a depth of about $190 \mathrm{~m}$ which were deposited on indurated volcanic deposits that separate the overlying freshwater-bearing alluvial aquifers from saline aquifers at depth (O'Leary et al. 2012). The depth to water varied seasonally, but typically ranged from about 15 to $20 \mathrm{~m}$ bls (Clark et al. 2012).

Multiple-well site 3D2-5 (STK-7; maximum depth of $174 \mathrm{~m}$ bls; Fig. 1) is located at the Stockton East Water District water treatment facility which is composed of a series of unlined recharge ponds as well as lined ponds used to store surface water prior to treatment and delivery to the City of Stockton and agricultural customers. In 2012 and 2013, 24 ha of unlined ponds at the facility were available to recharge the underlying alluvial deposits near the southern edge of a large regional pumping depression (Fig. 2). Test-drilling data show alluvial deposits consisting of interbedded gravel, sand, silt, and clay to a depth of about $195 \mathrm{~m}$ with increasing mafic minerals present below about $110 \mathrm{~m}$ (Fig. S2 of the ESM).

Water levels in the recharge pond at Morada Lane fluctuate more than those in the ponds at Stockon East, and water-level changes in the shallowest monitoring wells at each site are more pronounced at Morada Lane than at Stockton East (Figs. S3 and S4 of the ESM). The magnitude and timing of pressure changes in monitoring wells in response to artificial recharge were evaluated at the Morada Lane site; the magnitude of the pressure response decreases with depth while the time to the pressure response increases with increasing depth (Fig. 12 and Fig. S3 of the ESM).

Tritium and carbon-14 data were used to evaluate physical movement of artificial recharge to depth at each site. The physical movement of water to depth in response to artificial recharge follows a pattern similar to the pressure responses at Morada Lane, although the physical movement of water to depth is much slower than the propagation of the pressure response (O'Leary et al. 2012). Tritium and carbon-14 data show movement of modern water (tritium $\geq 0.6 \mathrm{pCi} / \mathrm{L}$ ) to at least $91 \mathrm{~m} \mathrm{bls}$ at Morada Lane (11H6; $87 \mathrm{pmC})$, whereas modern water is only present in the shallowest monitoring well at $50 \mathrm{~m}$ bls at Stockton East (3D5; 95 pmC; Fig. 12), indicating that movement of modern recharge water from land surface at STK-7 is much shallower than that observed at STK-2 (50 m versus $91 \mathrm{~m}$, respectively). Similarly, more negative (lighter) stable isotopes are only present in the shallowest monitoring well at STK-7 (3D5), while they are present to greater depths at STK-2. This difference may be associated with changes in subsurface geology indicated by geologic and geophysical log data reflecting increasing consolidation, changing lithology, increasing clay content, and decreasing permeability/interconnectedness of deeper deposits. Data show the increased consolidation/clay content of sediments occurs at shallower depths below the Stockton East facility (3D2-5) to the south than at the Morada facility (11H4-8) to the north (Fig. 12). Artificial recharge percolation depths and general groundwater age determined from tritium and carbon-14 data were in agreement with results from previously conducted sulfur hexafluoride tracer tests at the Morada facility (Moran et al. 2009).

Well-bore flow logs were collected from production wells $11 \mathrm{H} 3$ and $4 \mathrm{G} 1$, which are located in the vicinity of the Morada and Stockton East facilities, respectively (Fig. 1). Flow logs collected from these wells were comparatively heterogeneous with large portions of the overall flow to each well contributed through relatively

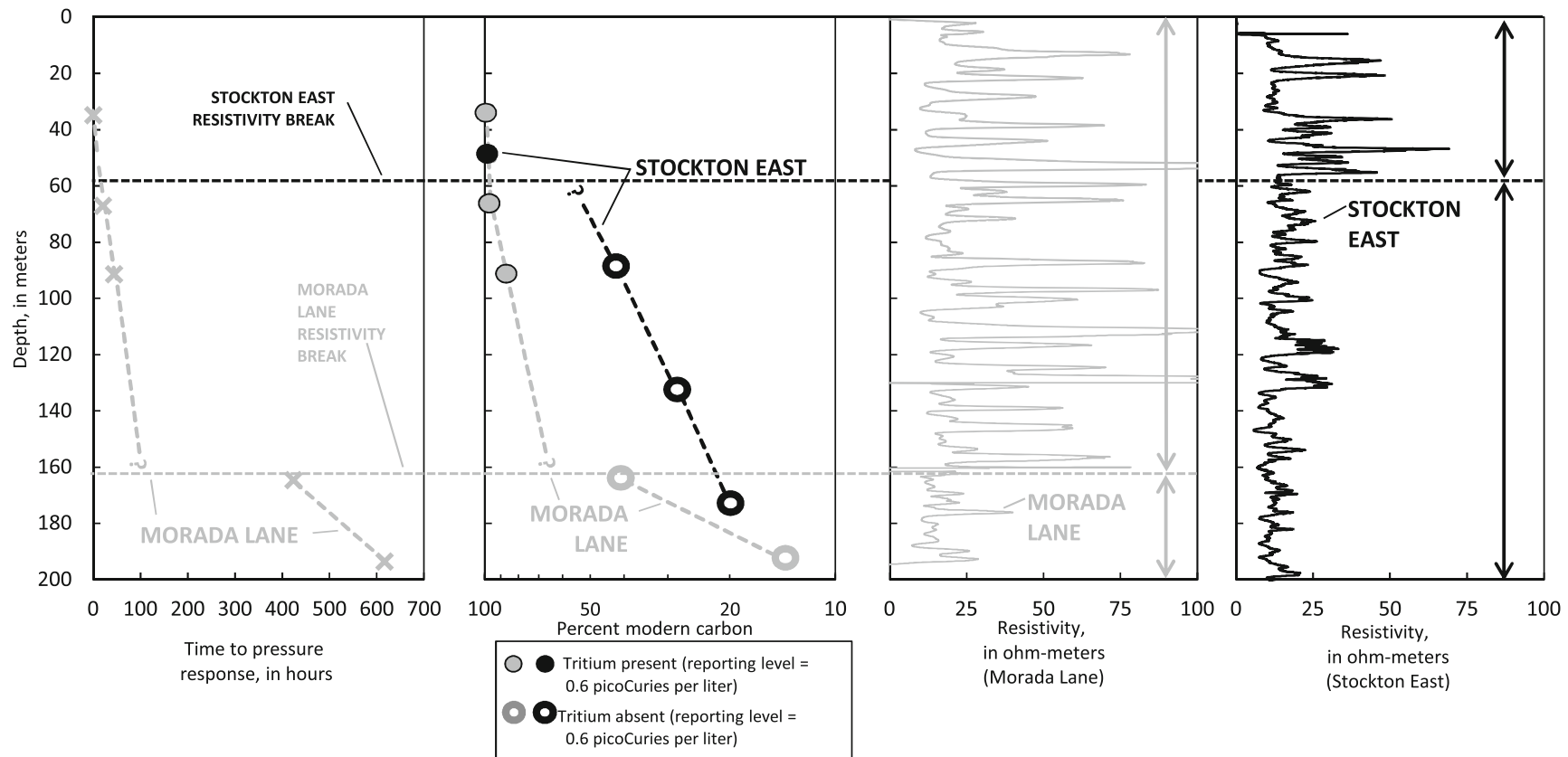

Fig. 12 Time-to-pressure response, tritium and percent modern carbon data, and resistivity logs for monitoring site 3D2-5 (Stockton East) and 11H4-8 (Morada Lane). Note: RESISTIVITY BREAK situated at a depth where resistivity readings generally decrease 
thin intervals, with well 4G1 exhibiting more heterogeneous flow than $11 \mathrm{H} 3$ (Table 1). A significant portion of well 4G1's heterogeneity is due to the large contribution of flow near the top of the screened interval near the break in resistivity in the geophysical log (Figs. 12 and S5 of the ESM).

Based on test drilling data, the shallow aquifer system within the subbasin is generally comprised of interconnected layers of silts, sands, and gravels with increasing consolidation and clay content with depth. As noted, the increased consolidation/clay content of sediments is located at shallower depths below the Stockton East facility (3D2-5) to the south than at the Morada facility $(11 \mathrm{H} 4-8)$ to the north. This difference is manifested in the physical movement of recharge water moving to much greater depths at the Morada facility (Fig. 12). Similarly, depth-dependent water-quality data collected from production wells $20 \mathrm{~N} 1$ and $28 \mathrm{~F} 1$, located in the southern portion of Stockton (Fig. 1), have large variations in stable isotopes and age data, indicating relative isolation between shallow and deep systems. It appears that the physical movement of water is deeper to the north where interconnected sands of granitic origin are present at greater depths. To the south there appears to be a relatively shallow geologic contrast between the upper and lower system that affects the movement of water at depth. Although volcanic deposits generally were not encountered as part of test drilling, mafic minerals possibly indicative of volcanically derived (at least partially) alluvium, were observed to be present at shallower depths in 3D2-5 (STK-7) to the south than $11 \mathrm{H} 4-8$ (STK-2) to the north. Differences in the physical movement of recharge water with depth related to subsurface geologic conditions may influence the usefulness of managed groundwater recharge to control highchloride groundwater.

\section{Summary and conclusions}

As a result of pumping in excess of recharge, water levels in the Eastern San Joaquin Subbasin have declined to below sea-level, and increasing chloride concentrations in water from some wells have exceeded the USEPA SMCL of $250 \mathrm{mg} / \mathrm{L}$. Some public-supply wells have been removed from service due to high-chloride concentrations. Although water levels have recovered from historic lows and chloride concentrations have decreased in portions of the aquifer, water levels remain below sea level in some area and water-quality issues associated with highchloride concentrations persist.

Eight multiple-well monitoring sites, each containing 3-5 PVC-cased monitoring wells, were installed by the USGS in the study area between 2003 and 2012. Alluvial deposits encountered during test drilling tended to be heterogeneous consisting of alternating layers of sands, silts, and clays. Alluvial materials encountered during test drilling were generally of felsic/granitic origin, although increasing mafic minerals were encountered at depth in several boreholes. Pressure gradients at multiple well monitoring sites were generally downward, although water levels in the deepest monitoring well installed indicate the potential for an upward hydraulic gradients at depth. Water levels fluctuated seasonally, with maximum declines in the summer months of greater than $4 \mathrm{~m}$ when groundwater pumping was greatest.

Sources of high-chloride water to wells include irrigation return, high-chloride water from delta sediments, and high-chloride water from deeper aquifers. In many cases, high-chloride water can be attributed to more than one source. On the basis of chloride-to-iodide ratios, sources of high-chloride water to wells include irrigation return in $16 \%$ of sampled wells, and high-chloride water from delta sediments and/or deeper groundwater in $50 \%$ of sampled wells. The highest chloride concentrations were found in wells affected by delta sources. Sequential electromagnetic logs collected from multiple-well monitoring sites show high-chloride water can move from the delta toward pumping wells through highly permeable interconnected aquifer layers, ranging from 1 to $7 \mathrm{~m}$ thick. Consistent with previous work, movement of highchloride water from delta sediments and deeper sources to wells was occurring in the northern part of the study area and to a lesser extent in the southern part of the study area.

The $\delta^{18} \mathrm{O}$ and $\delta \mathrm{D}$ composition of most water samples plot parallel and slightly below the global meteoric water line along a local meteoric water line. Recently recharged, lighter groundwater containing tritium is present in wells along the major rivers in the study area (the Mokelumne and Stanislaus), and in shallower aquifers receiving return from irrigation water from surface sources. In contrast to water from rivers draining the higher altitudes of the Sierra Nevada, most of the groundwater within the subbasin is isotopically heavier and was recharged from lower altitudes along the eastern front of the Sierra Nevada. The absence of tritium and lower carbon-14 activities in this water suggests relatively low recharge rates when compared to the areas recharged by the major rivers, and increasingly negative $\delta \mathrm{D}$ compositions with decreasing carbon-14 activities suggest recharge from the front of the Sierra Nevada may have declined over recent geologic time.

Managed aquifer recharge through infiltration of water from ponds at two sites was successful in affecting water levels in underlying aquifers. The physical movement of water to depth, as confirmed by tracer test results (Morada Lane only) and tritium and carbon-14 data, was greater at Morada Lane than Stockton East. The differences are related to changes in subsurface geology including increasing consolidation and clay content with depth. Similar to the movement of high-chloride water, the movement of recharge water toward pumping wells is through thin highpermeability interconnected aquifer layers. Managed aquifer recharge can be used throughout the study area, although the response to recharge with depth differs at different sites. Well-bore flow data suggest aquifer heterogeneity may promote rapid movement of recharged water to wells 
throughout the study area. Physical movement of recharged water with depth was inhibited by increasing consolidation and clay content with depth. Similarly, heterogeneous deposits with laterally extensive confining layers may inhibit surface recharge from reaching screened sections of nearby production wells.

Aquifer heterogeneity is important in the movement of recharged water and high-chloride water to pumping wells causing water to move rapidly through highly permeable interconnected layers. Managed aquifer recharge that benefits water supply by raising water levels also will benefit water quality by reestablishing hydraulic gradients that limit the movement of high-chloride water from deeper sources and sediments in the San Joaquin Delta. The thin permeable interconnected layers within the alluvial deposits will transmit pressure responses and percolated water associated with recharge more rapidly over greater distances than would be expected in more homogeneous deposits.

Acknowledgements This study was funded by the Eastern San Joaquin County Groundwater Basin Authority (ESJCGBA) and the California Department of Water Resources, in cooperation with the US Geological Survey. The authors thank the management and staff of the ESJCGBA, the City of Stockton Municipal Utilities Department, Stockton East Water District, and the many land owners who granted permission to access their property to sample wells. Special thanks are extended to the Brandon Nakagawa, Gerardo Dominguez, and the Board members of the ESJCGBA; Mel Lytle (formerly of the ESJCGBA) and Anthony Tovar of the City of Stockton Municipal Utilities District; Andreas Lozano of Stockton East Water District; Michael Infurna of the San Joaquin County Public Health Department; Jason Preese of the California Department of Water Resources; and the management and staff of other participating water agencies in the Stockton area for their assistance with this study.

Open Access This article is distributed under the terms of the Creative Commons Attribution 4.0 International License (http:// creativecommons.org/licenses/by/4.0/), which permits unrestricted use, distribution, and reproduction in any medium, provided you give appropriate credit to the original author(s) and the source, provide a link to the Creative Commons license, and indicate if changes were made.

\section{References}

Anders R, Fisher RN, O’Leary DR, Futa K, Danskin WR (2013) Evidence for a brackish to hypersaline paleodepositional environment, San Elijo Lagoon, California. 22nd Biennial Conference of the Coastal and Estuarine Res Federation, San Diego, CA, 3-7 November 2013

Barlow PM, Reichard EG (2010) Saltwater intrusion in coastal regions of North America. Hydrogeol J 18(1):247-260

Bennett GL, Fram MS, Belitz K, Jurgens BC (2010) Status and understanding of groundwater quality in the Northern San Joaquin Basin, 2005: California GAMA Priority Basin Project. US Geol Surv Sci Invest Rep 2010-5175

Burow KR, Shelton JL, Hevesi JA, Weissmann GS (2004) Hydrogeologic characterization of the Modesto area, San
Joaquin Valley California. US Geol Surv Sci Invest Rep 2004$5232,54 \mathrm{pp}$

California Department of Water Resources (DWR) (1967) San Joaquin County investigation: Bulletin 146. California Dept of Water Resources, Sacramento, CA

California Department of Water Resources (DWR) (2006) California's groundwater, San Joaquin Valley groundwater basin, Eastern San Joaquin subbasin: Bulletin 118. California Dept. of Water Resources, Sacramento, CA.http:// www.water.ca.gov/groundwater/bulletin 118/basindescriptions/ 5-22.01.pdf. Accessed 21 September 2012, 6 pp

Clark DA, Izbicki JA, Metzger, LF, Everett RR, Smith GA, O'Leary DR, Teague NF, Burgess MK (2012) Groundwater data for selected wells within the Eastern San Joaquin Groundwater Subbasin, California, 2003-8. US Geol Surv Data Series 696, $154 \mathrm{pp}$

Condor Earth Technologies (2006) WID recharge operations report: 2006 Operations SJAFCA Detention Basin no. 2. Municipal Utilities Dept., Stockton, CA

Craig H (1961) Isotopic variation in meteoric waters. Science 133:1702-1703

Curtis GH (1954) Mehrten formation of the Sierra Nevada. Univ Cali Publ Geol Sci 29(9):453-502

Downtown Stockton Alliance (2008) Stockton's famous mineral baths. http://www.downtownstockton.org/stockton_history.php\#baths. Accessed May 2013

Edwards BD, Ehman KD, Ponti DJ, Reichard EG, Tinsley JC, Rosenbauer RJ, Land M (2009) Stratigraphic controls on saltwater intrusion in the Dominguez Gap area of coastal Los Angeles. In: Lee HJ, Normark WR (eds) Earth science in the urban ocean: the southern California continental borderland. Geol Soc Am Spec Pap 454:375-395. doi:10.1130/ 2009.2454(5.4)

Faunt CC (2009) Groundwater availability of the Central Valley Aquifer. Calif US Geol Surv Prof Pap 1766:225

Friedman I, Smith GI (1970) Deuterium content of snow cores from Sierra Nevada area. Science 169:467-470

Friedman I, Smith GI (1972) Deuterium content of snow as an index to winter climate in the Sierra Nevada area. Science 176:790793

Friedman I, Smith GI, Gleason JD, Warden A, Harris JM (1992) Stable isotope composition of waters in southeastern California, 1: modern precipitation. J Geophys Res 97:5795-5812

Garcia CA, Halford KJ, Laczniak RJ (2010) Interpretation of flow logs from Nevada Test Site boreholes to estimate hydraulic conductivity using numerical simulations constrained by singlewell aquifer tests. US Geol Surv Sci Invest Rep 2010-5004, 28 pp. http://pubs.usgs.gov/sir/2010/5004/. Accessed March 2013

Gonfiantini R (1978) Standards for stable isotope measurements in natural compounds. Nature 217:534-536

Hammer MJ, Elser G (1980) Control of ground-water salinity, Orange County, California. Ground Water 18(6):536-540

Hanson RT (2003) Geohydrologic framework of recharge and seawater intrusion in the Pajaro Valley, Santa Cruz and Monterey counties, California. US Geol Surv Water Res Invest Rep 3-4096

Hill AD (1990) Production logging: theoretical and interpretive elements. SPE Monograph 14, SPE, Richardson, TX, 145 pp

Ingraham NL, Taylor BE (1991) Light stable isotope systematics of large-scale hydrologic regimes in California and Nevada. Water Resour Res 27:77-90

Izbicki JA (1991) Chloride sources in a California coastal aquifer. In: Ground water in the Pacific Rim countries, IR Div ASCE Proceedings, Am. Soc. Civil Eng., Washington, DC, pp 71-77

Izbicki JA (1996) Seawater intrusion in a California coastal aquifer. US Geol Surv Fact Sheet FS-125-96, 4 pp

Izbicki JA (2004) A small-diameter sample pump for collection of depth-dependent samples from production wells under pumping conditions. US Geol Surv Fact Sheet 2004-3096, http:// pubs.usgs.gov/fs/2004/3096/. Accessed September 2014

Izbicki JA, Christensen AH, Hanson RT, Martin PM, Crawford SM, Smith GA (1999) U.S. Geological Survey combined well-bore 
flow and depth-dependent water sampler. US Geol Surv Fact Sheet 196-99, 2 pp. http://pubs.er.usgs.gov/usgspubs/fs/ fs 19699 . Accessed September 2014

Izbicki JA, Borchers JW, Leighton DA, Kulongoski J, Fields L, Galloway DL, Michel RL (2003) Hydrogeology and geochemistry of aquifers underlying the San Lorenzo and San Leandro areas of the East Bay Plain, Alameda County, California. US Geol Surv Water Resour Invest Rep 02-4259, 61 pp. http://pubs.usgs.gov/wri/ wrir024259/text.html. Accessed February 2014

Izbicki JA, Christensen AH, Newhouse MW, Aiken GR (2005) Inorganic, isotopic, and organic composition of high-chloride water from wells in a coastal southern California aquifer. Appl Geochem 20:1496-1517

Izbicki JA, Metzger LF, McPherson KR, Everett RE, Bennett GL (2006) Sources of high-chloride water to wells, Eastern San Joaquin Ground-Water subbasin, California. US Geol Surv Open File Rep 2006-1309

Izbicki JA, Stamos CL, Metzger LF, Halford KJ, Kulp TR, Bennett GL (2008) Source, distribution, and management of arsenic in water from wells, Eastern San Joaquin Ground-Water subbasin, California. US Geol Surv Open File Rep 2008-1272, 8 pp

Izbicki JA, Petersen CE, Glotzbach KJ, Metzger LF, Christensen AH, Smith GA, O'Leary DR, Fram MS Joseph T, Shannon H (2010) Aquifer storage recovery (ASR) of chlorinated municipal drinking water in a confined aquifer. Appl Geochem 25:11331152

Jones BF, Vengosh A, Rosenthal E, Yechiele Y (1999) Geochemical Investigations, chap 3. In: Bear J, Cheng AH, Sorek S, Ouazar D, Herrera I (eds) Seawater intrusion in coastal aquifers: concepts, methods, and 860 practices. Kluwer, London, pp 51-71

Kalin RM (2000) Radiocarbon dating. In: Cook PG, Herczeg AL (eds) Environmental tracers in subsurface hydrology. Kluwer, Boston, pp 111-144

Mendenhall WC (1905) Development of underground waters in the central coastal plain region of southern California. US Geol Surv Water Suppl Pap 138:162

Mendenhall WC (1908) Ground waters of the San Joaquin Valley, California. US Geol Surv Water Suppl Pap 222:52

Metropolitan Water District of Southern California (2007) Groundwater basin reports northwest metropolitan service area: Ventura County basins, September 2007. http://www.mwdh2o.com/ $\mathrm{mwdh} 2 \mathrm{o} / \mathrm{pages} /$ yourwater/supply/groundwater/PDFs/ NorthwestMetropolitanBasins/VenturaCountyBasins.pdf. Accessed 6 August 2014

Metzger LM, Izbicki JA (2012) Electromagnetic-induction logging to monitor changing chloride concentrations. Groundwater 51(1):108-121. doi:10.1111/j.1745-6584.2012.00944.x/full

Metzger LM, Izbicki JA, Nawikas JM (2012) Test drilling and data collection in the Calaveras County portion of the Eastern San Joaquin groundwater subbasin, California, December 2009June 2011. US Geol Surv Open File Rep 2012-1049

Moran JE, Singleton MJ, McNab WW, Leif D, Esser BK (2009) California GAMA Program: tracking water quality changes during groundwater banking at two sites in San Joaquin County. LLNL-TR-412861, LLNL, Livermore, CA

Neter J, Wasserman W (1974) Applied linear statistical models. Irwin, Homewood, IL, 842 pp

Northeastern San Joaquin County Groundwater Banking Authority (2004) Eastern San Joaquin Basin Groundwater Management
Plan. Northeastern San Joaquin Groundwater Banking Authority, Stockton, CA

O'Leary DR, Izbicki JA, Moran JE, Meeth T, Nakagawa B, Metzger L, Bonds C, Singleton MJ (2012) Movement of water infiltrated from a recharge basin to wells. Groundwater 50(2):242-255

Paillet FL (2000) Flow logging in difficult boreholes: making the best of a bad deal. In: Proc. of the 7th Int. Symp. on Borehole Geophysics for Minerals, Geotechnical, and Groundwater Applications, Denver, CO, 2000, Minerals and Geotechnical Logging Society, Houston, TX, pp 125-135

Piper AM (1945) A graphic procedure in the geochemical interpretation of water analyses. Am Geophys Union Trans 25th Ann Meeting, AGU, Washington, DC, pp 914-928

Piper AM, Garrett AA (1953) Native and contaminated ground waters in the Long Beach-Santa Ana areas, California. US Geol Surv Water Suppl Pap 1136, 320 pp

Piper AM, Gale HS, Thomas HE, Robinson TW (1939) Geology and ground-water hydrology of the Mokelumne area, California. US Geol Surv Water Suppl Pap 780, 270 pp

Reichard EG (1995) Groundwater-surface water management with stochastic surface water supplies: a simulation optimization approach. Water Resour Res 31(11):2845-2865

Reichard EG, Land M, Crawford MT, Johnson T, Everett RR, Tulshan TV, Ponti DJ, Halford KL, Johnson TA, Paybins KS, Nishikawa T (2003) Geohydrology, geochemistry, and groundwater simulation optimization of the Central and West Coast Basins, Los Angeles County, California. US Geol Surv Water Resour Invest Rep 03-4065. http://pubs.water.usgs.gov/ wri034065/. Accessed February 2014

San Joaquin County Public Works Department, Water Resources Division (2014) Internal Groundwater Data Center, Stockton, CA. http://www.sjmap.org/groundwater/. Accessed October 2014

Shammas MI (2008) The effectiveness of artificial recharge in combating seawater intrusion in Salalah coastal aquifer, Oman. Environ Geol 55(1):191-204

Solomon DK, Cook PG (1999) ${ }^{3} \mathrm{H}$ and ${ }^{3} \mathrm{He}$. In: Environmental tracers in subsurface hydrology, Kluwer, Boston, pp 397-424

Stockton East Water District (2014) Farmington Groundwater Recharge Program. http://www.farmingtonprogram.org/ about.html. Accessed 21 November 2014

Tularam GA, Krishna M (2009) Term consequences of groundwater pumping in Australia: a review of impacts around the globe. J Appl Sci Environ Sanit 4(2):151-166

USGS (US Geological Survey) (variously dated) National field manual for the collection of water-quality data. Techniques of Water Resources Investigations, book 9, chap A1-A9, USGS, Reston, VA. http://pubs.water.usgs.gov/twri9A. Accessed February 2014

USGS National Water Information System Web (NWISWeb) (2015) USGS National Water Information System Web page. http:// waterdata.usgs.gov/nwis/. June 2015

Western Regional Climate Center (2012) Stockton WSO, California (048558): period of record monthly climate summary-1948 to 2005. http://www.wrcc.dri.edu/cgi-bin/cliMAIN.pl?castoc+nca. Accessed 21 September 2012

Williams JH, Lapham WW, Barringer TH (1993) Application of electromagnetic logging to contamination investigations in glacial sand-and-gravel aquifers. Ground Water Monit Remed 13(3):129-138 